\title{
PERANCANGAN APLIKASI DONOR DARAH
}

Muhammad Virgi 19666010

Nur Syadina 19666028

Nur Hidayah 19666029

Program Studi D4 Teknologi Rekayasa Komputer

Jurusan Teknologi Informasi, Politeknik Negeri Samarinda

\begin{abstract}
Abtrak
Kurangnya informasi ketersediaan stok darah serta sulitnya ketersediaan pendonor darah merupakan masalah penting dalam pemenuhan donor darah. Tujuan aplikasi Donor Darah yang kami rancang adalah: 1) Untuk mempermudah PMI memperoeh informasi dalam mencari pendonor darah. 2) Untuk mempermudah masyarakat memperoleh informasi mengenai kegiatan donor darah. 3) Untuk memfasilitas pendonor ketika mendonor.
\end{abstract}

\section{PENDAHULUAN}

Latar Belakang

Informasi merupakan data atau fakta yang dikelola menjadi sebuah pesan atau pemberitahuan yang memiliki arti dan makna yang bermanfaat.Informasi sendiri merupakan hal yang penting di dalam kehidupan manusia sehari-hari karena setiap orang membutuhkan informasi untuk membangun komunikasi, menambah pengetahuan, mendapatkan sumber berita, dll. Pada masa sekarang ini, masyarakat ingin membutuhkan dan memperoleh sebuah informasi dengan mudah dan cepat maka dari itu perkembangan teknologi sangat dibutuhkan dan dapat membantu manusia untuk mencari informasi, menyebarkan informasi, dll. Teknologi informasi membantu manusia untuk mengelola, membuat, mencari, menyimpan, dan mengkomunikasikan informasi dalam berbagai macam bentuk seperti gambar, tulisan, dan suara.

Perkembangan teknologi informasi mempengaruhi kegiatan manusia baik itu pada suatu bidang, organisasi atau pun aktivitas sehari-hari masyarakat. Salah satunya organisasi yang mengharuskan mengikuti perkembangan teknologi adalah organisasi Palang Merah Indonesia (PMI) yang harus menyesuaikan aktivitas sehari-hari manusia dalam menggunkan teknologi informasi. Pada saat ini masih ada organisasi Palang Merah Indonesia (PMI) dalam proses menyebarkan sebuah informasi masih sebatas melalui sosial media dan masyarakat yang masih minim memperoleh informasi terkait 
donor darah atau stok darah. Sehingga menjadi keterlambatan untuk memperoleh informasi baik bagi PMI yang sangat membutuhkan stok darah dan bagi masyarakat yang ingin mendonorkan darah karena kurang mengetahui mengenai informasi, jadwal, kegiatan donor darah, dll.

Penyebaran informasi mengenai donor darah perlu diketahui oleh masyarakat umum terutama masyarakat seluruh indonesia. Dengan tujuan untuk memberikan informasi kepada seluruh masyarakat Indonesia, agar semua masyarakat mengetahui informasi dan dapat berpatisipasi dalam kegiatan donor darah.

Dengan adanya perancangan aplikasi android donor darah mempermudah baik masyarakat sebagai user umum dan Palang Merah Indonesia (PMI) dalam memperoleh informasi karena dirancang terdapat proses pelayanan informasi, lokasi donor darah, penjadwalan serta memperoleh poin ketika setelah melakukan pendonoran darah yang dapat dilakukan secara komputerisasi sehingga memberikan kemudahan baik bagi PMI ataupun masyarakat dalam kegiatan donor darah.

\section{PENGEMBANGAN PRANGKAT LUNAK}

Definisi Metode Waterfall Model pengembangan software yang diperkenalkan oleh Winston Royce pada tahun 70-an ini merupakan model klasik yang sederhana dengan aliran sistem yang linier - keluaran dari tahap sebelumnya merupakan masukan untuk tahap berikutnya. Pengembangan dengan model ini adalah hasil adaptasi dari pengembangan perangkat keras, karena pada waktu itu belum terdapat metodologi pengembangan perangkat lunak yang lain.

Metode Waterfall adalah suatu proses pengembangan perangkat lunak berurutan, di mana kemajuan dipandang sebagai terus mengalir ke bawah (seperti air terjun) melewati fase-fase perencanaan, pemodelan, implementasi (konstruksi), dan pengujian. Dalam pengembangannya metode waterfall memiliki beberapa tahapan yang runtut: requirement (analisis kebutuhan), design sistem (system design), Coding \& Testing, Penerapan Program, pemeliharaan. Alasan kelompok kami menggunakan metode pengembangan perangkat lunak Waterfall adalah karena kebutuhan system yang kami rancang sudah cukup jelas dan prosesnya yang bertahap menguntungkan bagi kami. Tahapantahapan pada metode Watrfall ini harus dikerjakan bertahap dan berurutan sehingga setiap tahapannya dapat dikerjakan secara maksimal, ini artinya setiap tahapan harus dikerjakan secara benar agar dapat mengerjakan tahap selanjutnya. Berikut adalah tahapan-tahapan dalam metode Waterfall.

1. Requirement (Analisis Kebutuhan)

Dalam langkah ini merupakan analisa terhadap kebutuhan sistem. Pengumpulan data 
dalam tahap ini bisa melakukan sebuah penelitian, wawancara atau study literatur. Seseorang sistem analisis akan menggali informasi sebanyak-banyaknya dari user sehingga akan tercipta sebuah sistem komputer yang bisa melakukan tugas-tugas yang diinginkan oleh user tersebut. Tahapan ini akan menghasilkan dokumen user requirement atau bisa dikatakan sebagai data yang berhubungan dengan keinginan user dalam pembuatan sistem. Dokumen inilah yang akan menjadi acuan sistem analisis untuk menterjemahkan kedalam bahasa pemrograman.

Pada tahap ini, kelompok kami berdiskusi mengenai siapa penggunanya dan menentukan kebutuhan pengguna dengan cara memposisikan diri seolah-olah sebagai calon pendonor darah serta menentukan batasan-batasan software yang kami rancang. Setelah itu, hasil diskusi tersebut dianalisis sehingga mendapatkan data-data kebutuhan pengguna untuk megembangkan rancangan software yang kami tentukan, yaitu aplikasi Donor Darah.

\section{Design System (Desain Sistem)}

Proses desain akan menerjemahkan syarat kebutuhan ke sebuah perancangan perangkat lunak yang dapat diperkirakan sebelum dibuat koding. Proses ini berfokus pada : struktur data, arsitektur perangkat lunak, representasi interface, dan detail (algoritma) prosedural. Tahapan ini akan menghasilkan dokumen yang disebut software requirement. Dokumen inilah yang akan digunakan programmer untuk melakukan aktivitas pembuatan sistemnya.

Pada tahap ini, kami merancang gambaran mengenai tampilan dari sebuah sistem yang telah kami rancang. Perancangan system pada tahap ini menggunakan ERD berupa use case, kemudian membuat skenario, navigasi, LKT, jaringan semantik dan membuat prototype serta menentukan apakah aplikasi yang kami buat akan menggunakan 16 peinsip desain antarmuka yang menggambarkan secara spesifik mengenai aplikasi Donor Darah.

3. Coding and Testing (Penulisan Sinkode Program Implentasi)

Coding merupakan penerjemahan design dalam bahasa yang bisa dikenali oleh komputer. Dilakukan oleh programmer yang akan meterjemahkan transaksi yang diminta oleh user. Tahapan inilah yang merupakan tahapan secara nyata dalam mengerjakan suatu sistem.Dalam artian penggunaan computer akan dimaksimalkan dalam tahapan ini. Setelah pengkodean selesai maka akan dilakukan testing terhadap system yang telah dibuat tadi. Tujuan testing adalah menemukan kesalahankesalahan terhadap system tersebut dan kemudian bisa diperbaiki.

4. Penerapan / Pengujian Program (Integration \& Testing)

Tahapan ini bisa dikatakan final dalam pembuatan sebuah sistem. Setelah melakukan 
analisa, design dan pengkodean maka sistem yang sudah jadikan digunakan oleh user.

5. Pemeliharaan (Operation \& Maintence)

Perangkat lunak yang susah disampaikan kepada pelanggan pasti akan mengalami perubahan. Perubahan tersebut bisa karena mengalami kesalahan karena perangkat lunak harus menyesuaikan dengan lingkungan (periperal atau sistem operasi baru) baru, atau karena pelanggan membutuhkan perkembangan fungsional.

\section{PERANCANGAN TAMPILAN}

Prinsip Desain Antarmuka Pengguna

\section{a.User Compatibility}

User compatibility, aplikasi berbasis android ini dirancang sesuai dengan karakteritik user baik user umum dan user admin, yang mana user yang dapat mengakses aplikasi ini yang mempunyai KTP atau berusia diatas 17 tahun. Ketika user membuka aplikasi di android, aplikasi otomatis langsung menampilkan tampilan user interface halaman awal yang mana halaman tersebut terdapat menu- menu, fitur, ikon yang mudah diingat dan mudah dimengerti karena menggunakan ikon yang sering digunakan pada umumnya di aplikasi lain, keterangan atau penjelasan yang mudah dimengerti dan mudah dipahami serta tampilan aplikasi yang sederhana karena telah dirancang sesuai dengan karakteristik para user. Seperti gambar ilustrasi dibawah ini merupakan tampilan yang menampilkan tampilan user interface halaman awal aplikasi saat user pertama kali membuka aplikasi, seperti gambar ilustrasi dibawah ini merupakan tampilan awal aplikasi sebelum login dan sesudah login, tampilan user interface pada aplikasi ini seperti menu, fitur, ikon dan keterangan yang cukup mudah dimengerti karena sudah dipertimbangkan sesuai dengan karakteristik para user. 


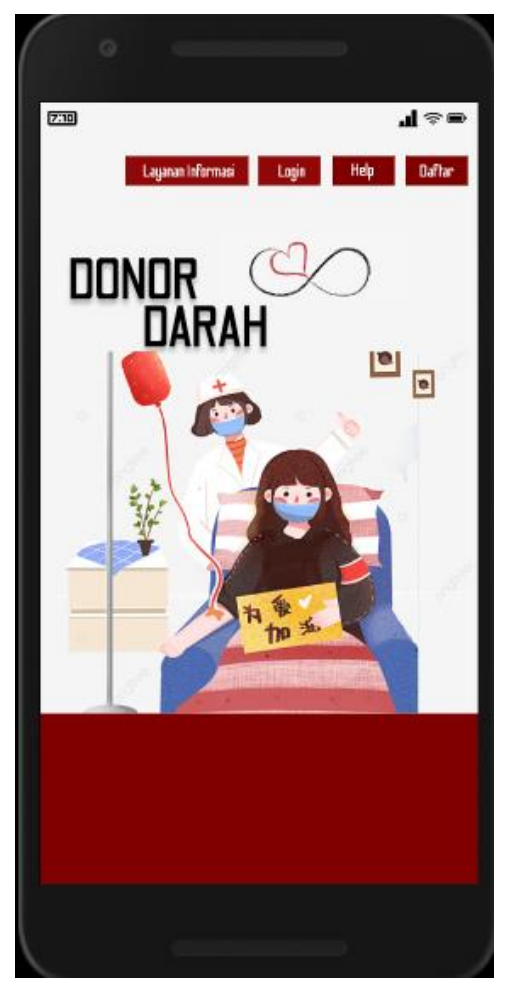

Gambar 3.1.1. 1 Ilustrasi Interface Awal Aplikasi Belum Login
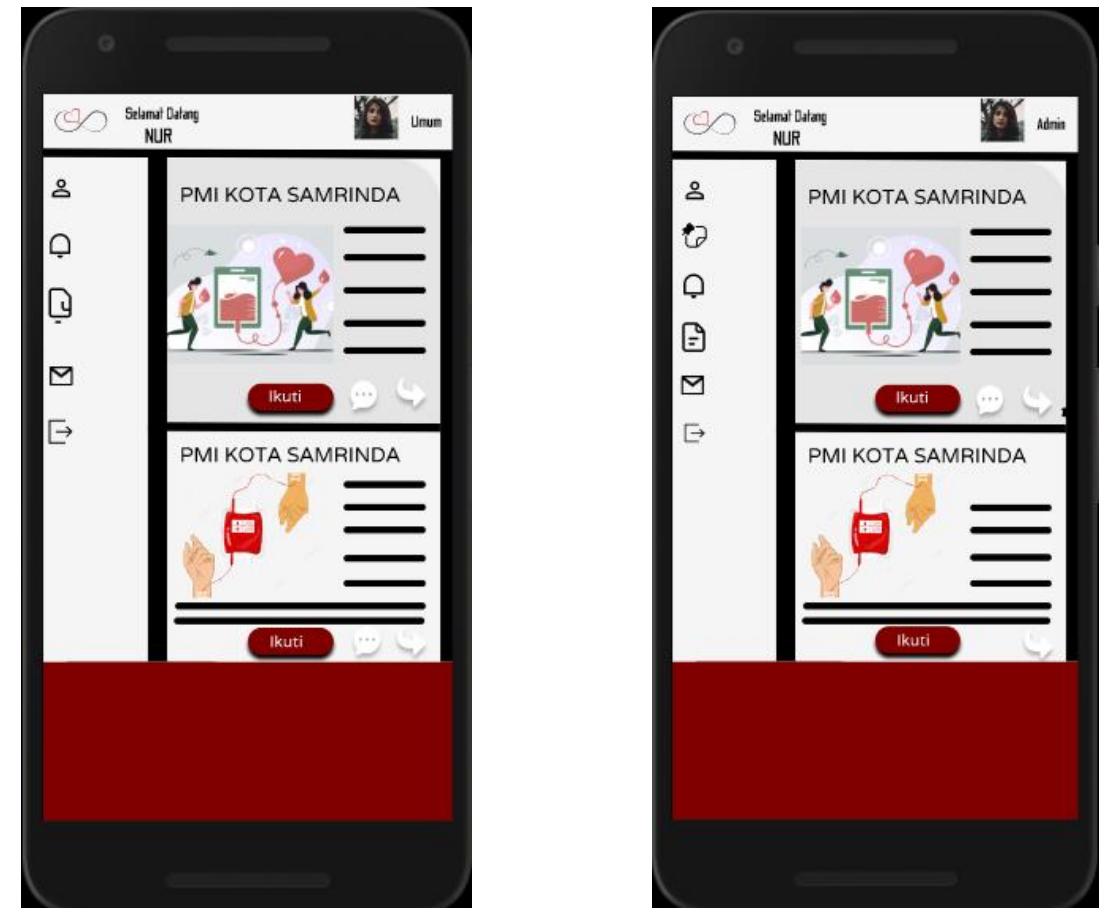

Gambar 3.1.1. 2 Ilustrasi Interface Awal Setelah Login 


\section{b.Product Compatibility}

Product compatibility, pada aplikasi halaman user umum terdapat fitur menu yaitu terdapat fitur menu riwayat, ketika user mendonor darah maka user mendapatkan sebuah poin, user dapat menukar poin tersebut dengan fasilitas yang telah disediakan oleh pihak PMI, kemudian aktivitas penukaran poin tersebut akan diolah sistem mengenai perhitungannya, yang mana proses tersebut akan keluar output di menu riwayat mengenai aktivitas penukaran poin tersebut terdapat isi transaksi berupa jumlah saldo yang diterima, dll. Jadi fitur riwayat transaksi pada menu user admin sudah dirancang sesuai dengan prinsip desain user interface pada fitur riwayat seperti gambar ilustrasi dibawah memberi keterangan bahwa 1 poin bernilai sejumlah uang Rp. 30.000, user menukar 2 poin maka user menerima saldo sebesar Rp. 60.000 ouput informasi pada sistem di aplikasi mempunyai informasi yang benar, detail dan akurat.

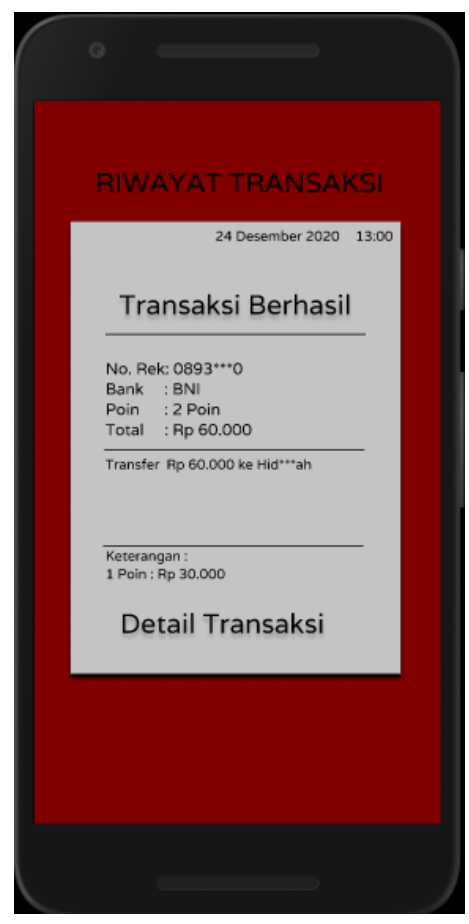

Gambar 3.1.2. 1 Ilustrasi Interface Riwayat Transaksi

\section{c.Work Flow Compatibility}

Fungsi pada aplikasi memiliki urutan kerja yang runtut dan hanya tersedia fungsi yang dibutuhkan oleh pengguna, Pada aplikasi Donor Darah pengguna diminta untuk menekan tombol „ikuti" untuk meminta persetujuan administrator apakah pengguna sesuai dengan kriteria yang diminta, jika disetujui barulah pengguna dapat mendonorkan darahnya dengan mendatangi lokasi yang telah diberitahukan melalui postingan agenda. 


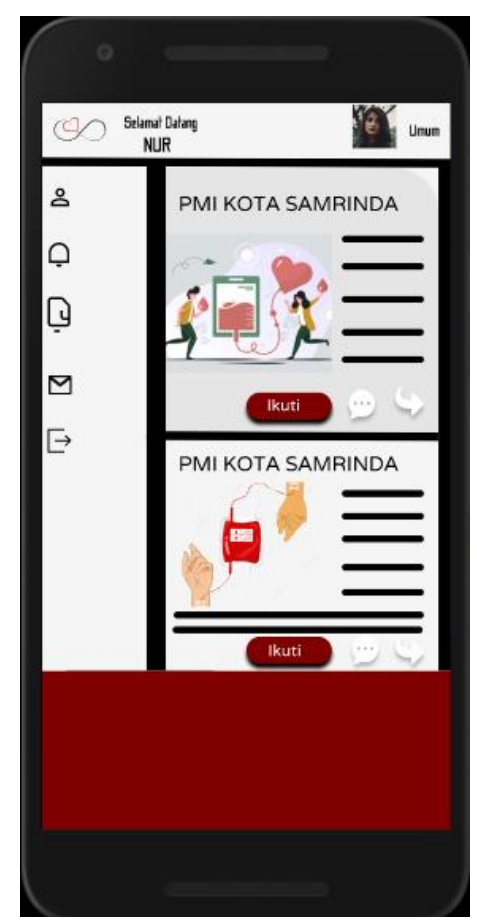

Gambar 3.1.4. 1 Ilustrasi Interface Pada Menu Highlight

\section{d.Consistency}

Cosistency adalah sebuah sistem yang harus sesuai dengan sistem nyata serta sesuai dengan produk yang dihasilkan. Pada aplikasi donor darah memiliki keseragaman antarmuka yaitu pada penerapan struktur menu, format desain, warna yaitu maroon, peach, dan putih di setiap menu bar dan navigasi sehingga user tidak mengalami kesulitan pada saat berpindah posisi atau lokasi dalam menyelesaikan suatu aktivitas. 


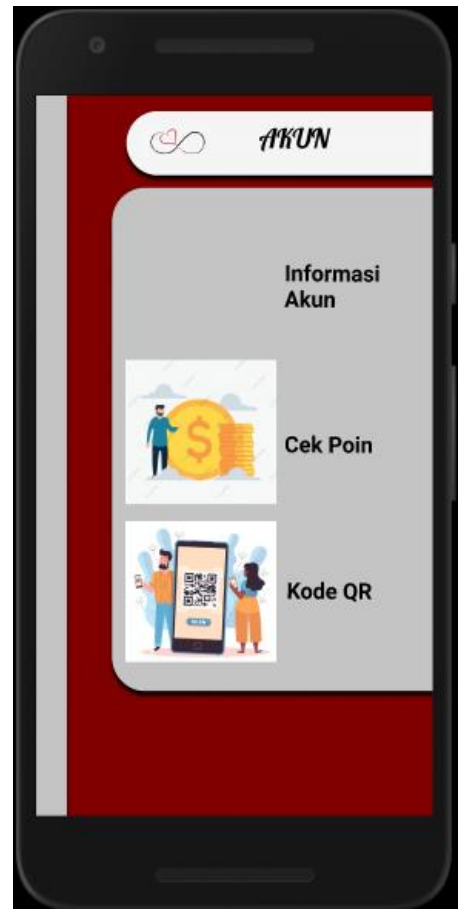

Gambar 3.1.5 1 Ilustrasi Interface Pada Menu Akun

\section{e.Familiarity}

Antarmuka sebisa mungkin didesain sesuai dengan antarmuka pada umumnya, dari segi tata letak, model, dan sebagainya. Pada aplikasi donor darah yang kami rancang, penggunaan dan penempatan tata letak menu bar dan navigasi serta model yang digunakan didesain sesuai dengan antarmuka pada umumnya sehingga dapat membantu user cepat berinteraksi dengan sistem melalui antarmuka yang familiar. 


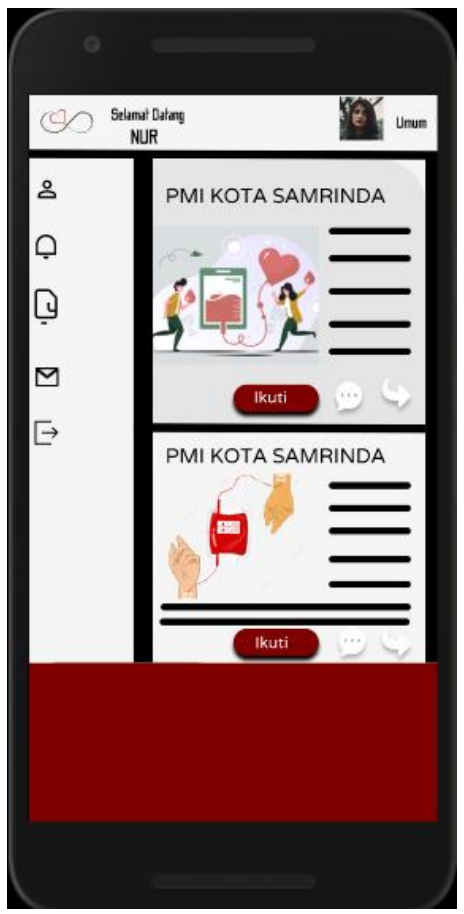

Gambar 3.1.6. 1 Ilustrasi Interface Pada Menu Highlight

\section{f.Simplicity}

Simplicity, adalah prinsip yang sangat penting juga untuk sebuah aplikasi dimana prinsip ini perlu di perhatikan untuk membangaun interface yang baik dan sederhana tidak terbelit-belit sehingga user merasa senang ketika mengakses aplikasi itu. Pada aplikasi Donor darah ini kesederhanaannya dapat dilihat dari Tampilan layar utamanya yang memiliki desain interface sederhana dan tetap berbobot di setiap menu- menunya. Contoh Pada menu pesan dimana menu tersebut user bisa langsung bertukar pesan dengan admin. 


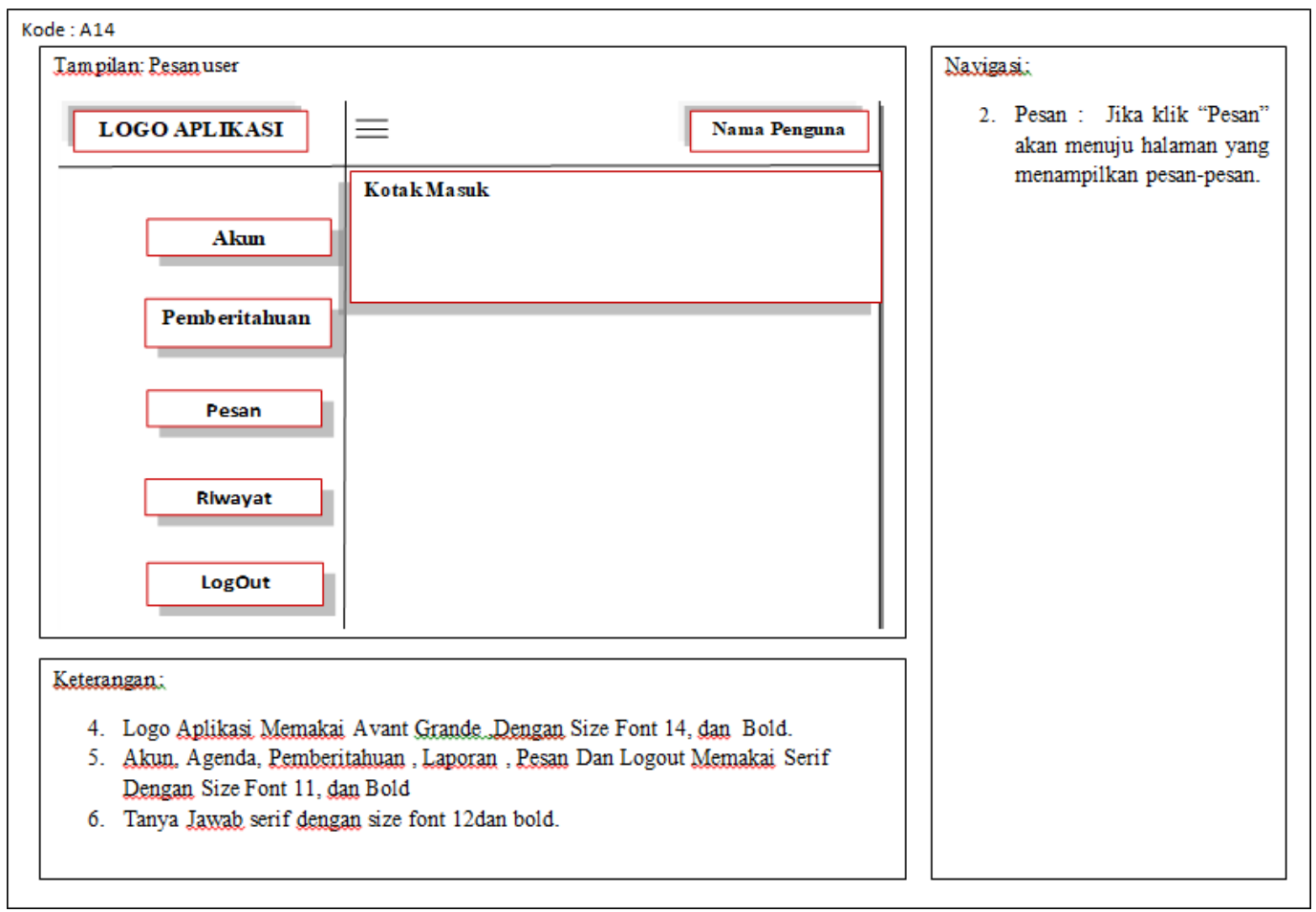

Gambar 3.1.7. 1 Simpicity Pada Aplikasi Donor Darah

\section{g.Direct Manipulation}

Direct manipulation, adalah salah satu sifat user yang sering kali bosan dengan aplikasi yang di gunakannya, user ingin sekali aplikasi yang di hadapinya dapat di sesuaikan dengan kebutuhan,sifat dan karakteristik dari user tersebut dimana jika aplikasi tersebut dapat di sesuaikan, maka rasa bosan user untuk memakai aplikasi tersebut sudah berkurang, Pada aplikasi donor darah ini terdapat pada menu akun dimana di akun tersebut user dapat mengganti profile akun saat pendaftaran dengan yang baru yang sesuai dengan keinginan user dengan begitu user bisa menggantinya kapan saja contoh : mengganti no hp dan email user bisa meng Klik > Menu > Akun > Informasi Akun lalu ke edit profile $>$ Menggubah no hp dan email > Selesai. 

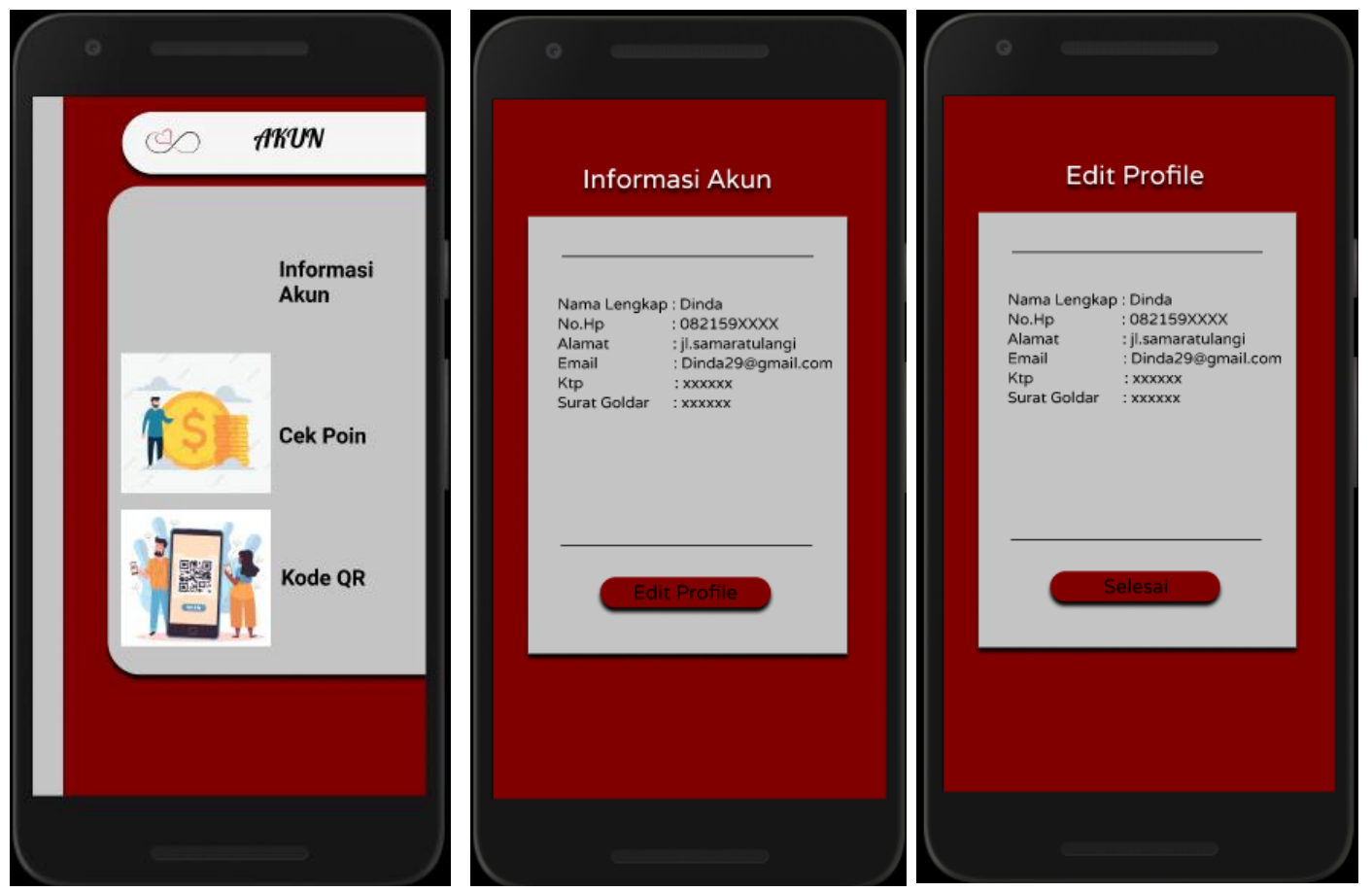

Gambar 3.1.8. 1 Direct manipulation Mengubah no. hp dan email pada akun

\section{h.What You See Is What You Get}

Dalam perancangan aplikasi "Donor Darah" ,sistem dirancang dengan sederhana sehingga memberikan kemudahan kepada user dalam mengoperasikan sistem ini. Dalam artian prinsip WYSIWYG ini yaitu sistem dapat memberikan dan memenuhi segala sesuatu sesuai dengan keinginan dan kebutuhan user saat sedang menggunakan sistem. WYSIWYG artinya apa yang diperoleh user sesuai dengan apa yang dilihat atau dikerjakan oleh user dalam sistem. Pengadaan prinsip WYSIWYG dalam perancangan sistem ini terlihat pada beberapa ilustrasi bagian yang terlihat sebagai berikut :

1. Saat user ingin melihat melihat seluruh informasi data pribadinya(akun) yang telah diinputkan pada saat proses mendaftar, user dapat mengakses menu Akun, setelahnya pilih Informasi Akun. Sistem akan menampilkan seluruh data diri dari si user yang diinputkan ketika mendaftar akun.

2. Jika user ingin melihat informasi poin yang telah diperolehnya, user hanya perlu mengakses menu Akun,setelahnya pilih Cek Poin. Sistem akan menampilkan informasi jumlah poin yang telah diperolehnya selama mengikuti kegiatan donor darah. 

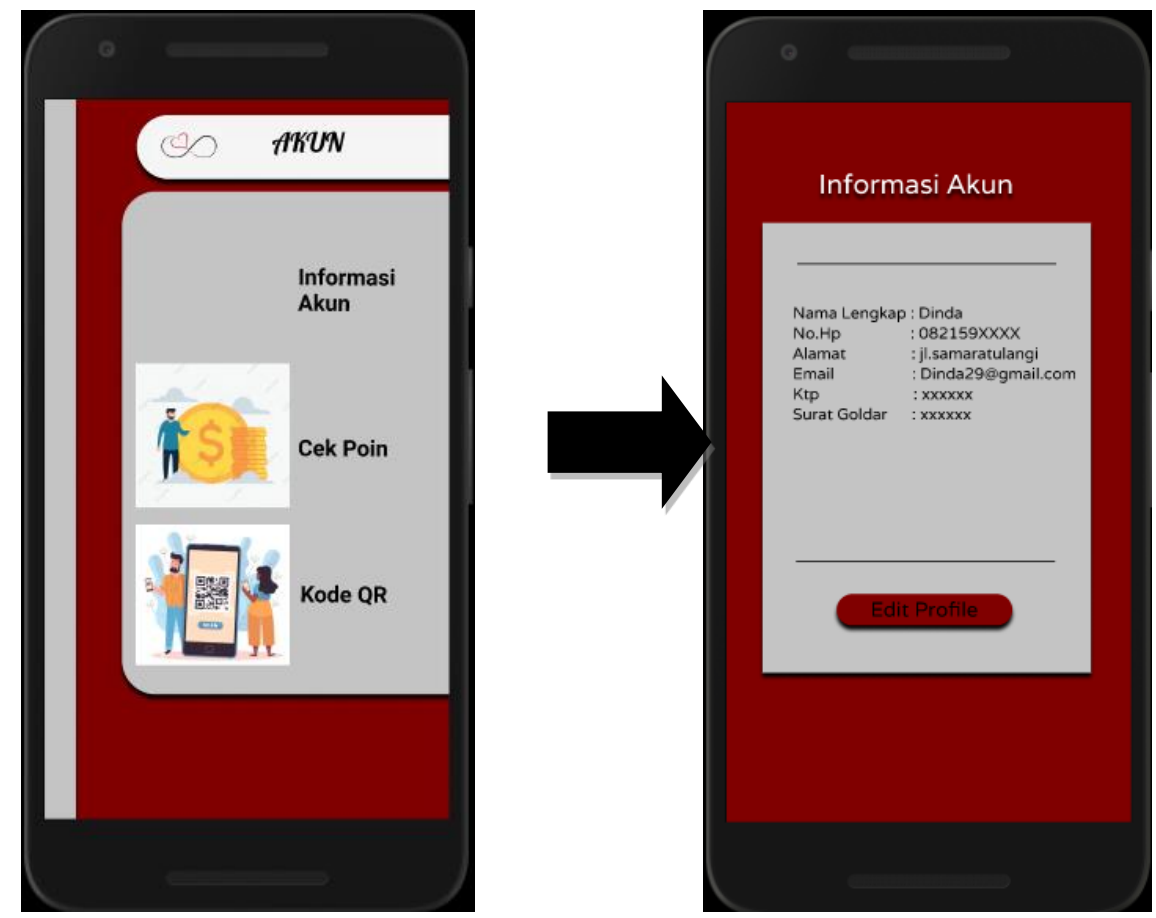

Gambar 3.1.9. 1 Ilustrasi WYSIWYG

\section{i.Flexibility}

Pengadaan prinsip ini tentu memerhatikan kesan fleksibel dalam sistem,artinya memberi kebebasan berupa solusi alternatif yang dapat memberi kemudahan user saat mengoperasikan sistem. Bentuk dari fleksibel ini sebagai suatu solusi saat kemungkinan user mengalami kendala. Adapun pengadaan prinsip Flexibility dalam perancangan aplikasi ini terdapat pada adanya solusi tindakan dalam penggunaan aplikasi yang dapat memberi kemudahan bagi user. Solusi tindakan tersebut berupa pilihan teknik dalam proses pencarian informasi bantuan pada bagian menu Help. Dimana dalam pencarian informasi bantuan tersebut, user bisa menggunakan voice maupun teks(papan ketik) sesuai kebutuhannya. 


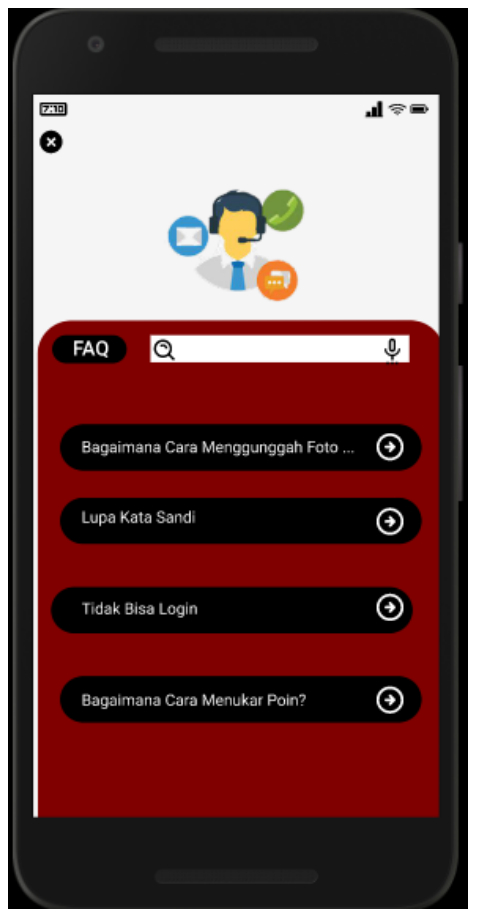

Gambar 3.1.10. 1 Ilustrasi Flexibility

\section{j.Responsiveness}

Prinsip ini sangat penting keberadaannya dalam sebuh sistem. Respon sistem yang baik terhadap kegiatan yang dilakukan oleh user ketika mengoperasikan sistem tentu akan meningkatkan kepahaman user terhadap tindakan yang dilakukannya. Pengadaan prinsip responsive ini dalam rancangan aplikasi terlihat pada ilustrasi bagian sebagai berikut:

Ketika user melakukan proses daftar akun,user akan menginputkan beberapa data pribadi sesuai ketentuan yang diminta oleh sistem. Setelah melengkapi data, user dapat mengakhiri proses daftar dengan mengklik "FINISH" agar data tersebut berhasil disimpan. Dalam proses penyimpanan data tersebut,sistem akan memberikan respon berupa informasi "Loading" yang menandakan bahwa sistem masih proses penyimpanan data. Sehingga user akan mengetahui sejauh mana proses yang berlangsung.Apabila proses penyimpanan data telah selesai dan berhasil, akan tampil informasi yang menyatakan bahwa proses tersebut telah selesai. 

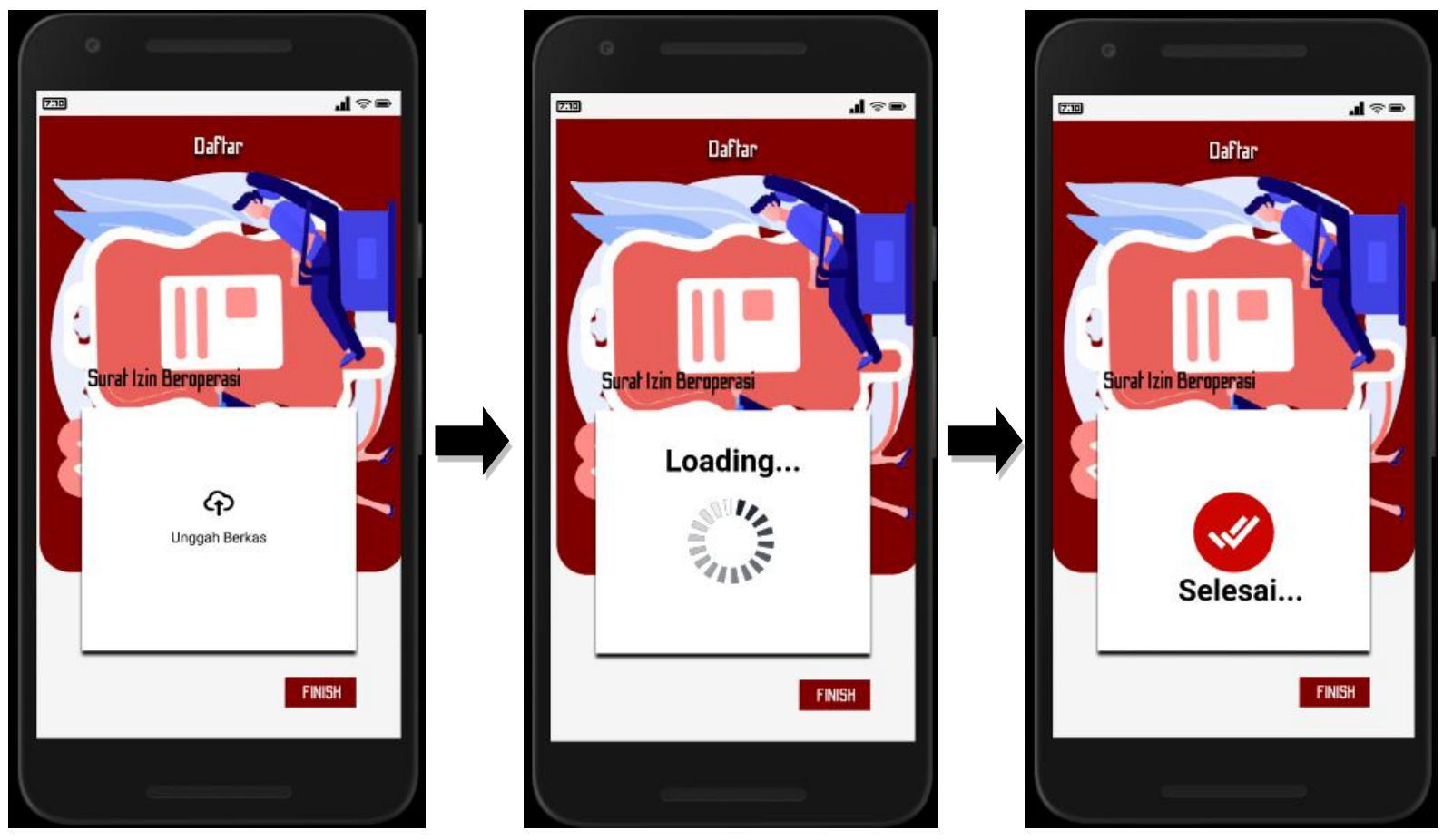

Gambar 3.1.11. 1 Ilustrasi Responsive

\section{k.Invisible Tehnology}

Prinsip desain ini memiliki arti teknologi yang tak kasat mata yang maksudnya adalah user tidak dapat mengetahui algoritma apa yang ada pada setiap proses dari perangkat lunak tersebut. Contoh dari prinsip invisible technology dari aplikasi donor darah ini terdapat pada proses penukaran (exchange) poin menjadi saldo di rekening bank.

Pada menu utama, terdapat menu Akun yang mempunyai sub menu Cek Poin. Sub menu Cek Poin ini menyediakan fitur Tukar Poin yang berguna untuk menukar poin yang telah terkumpul menjadi uang elektronik. Uang elektronik ini langsung diakumulasikan ke saldo pada rekening bank user. Proses pertukaran dan pengakumulasian ini tidak terlihat pada tampilan antar muka karena user tidak perlu tahu akan hal itu. User hanya mengetahui bahwa poinnya telah tertukar menjadi saldo di rekening bank-nya. 


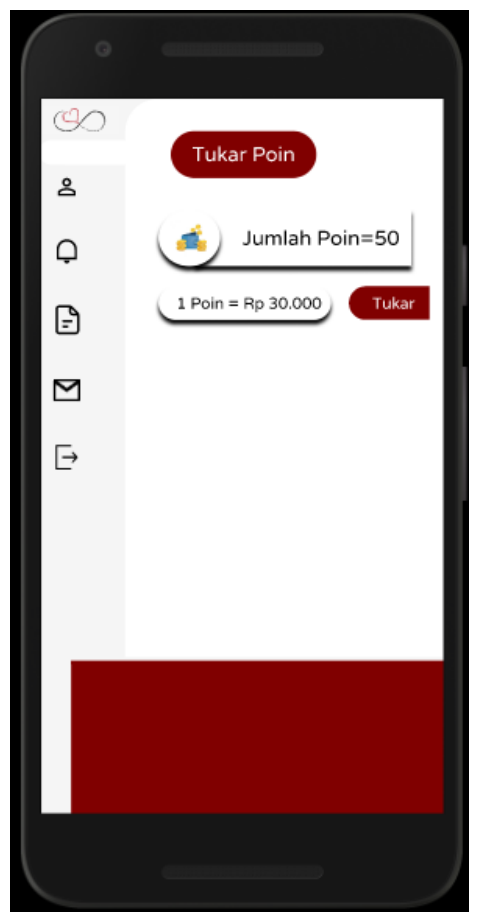

Gambar 3.1.12. 1 Invisible Technology pada Proses Penukaran Poin

\section{l.Robustness}

Prinsip desain ini memungkinkan sistem untuk menangani galat atau kesalahan dalam mengeksekusi suatu program. Ketika user melakukan kesalahan, sistem dapat mengirimkan pesan yang berisi keterangan dari kesalahan apa yang user alami. Pada aplikasi donor darah ini, prinsip robustness dapat ditemukan ketika user memasukkan berkas dengan format yang tidak sesuai saat proses pengunggahan pada menu pendaftaran. Sistem akan otomatis membaca kesalahan tersebut dan segera memberi pop up notification yang memuat keterangan bahwa format berkas yang user masukkan salah sehingga user perlu mengunggah ulang berkas sesuai dengan format yang diminta, yaitu DOC atau PNG. Begitu juga ketika user menlakukan kesalahan ketika memindai QR Code. Sistem akan mengirimkan pesan cepat kepada user bahwa kode QR yang ia pindai tidak bisa terbaca. Oleh karena itu, user diminta untuk melakukan pemindaian ulang. 

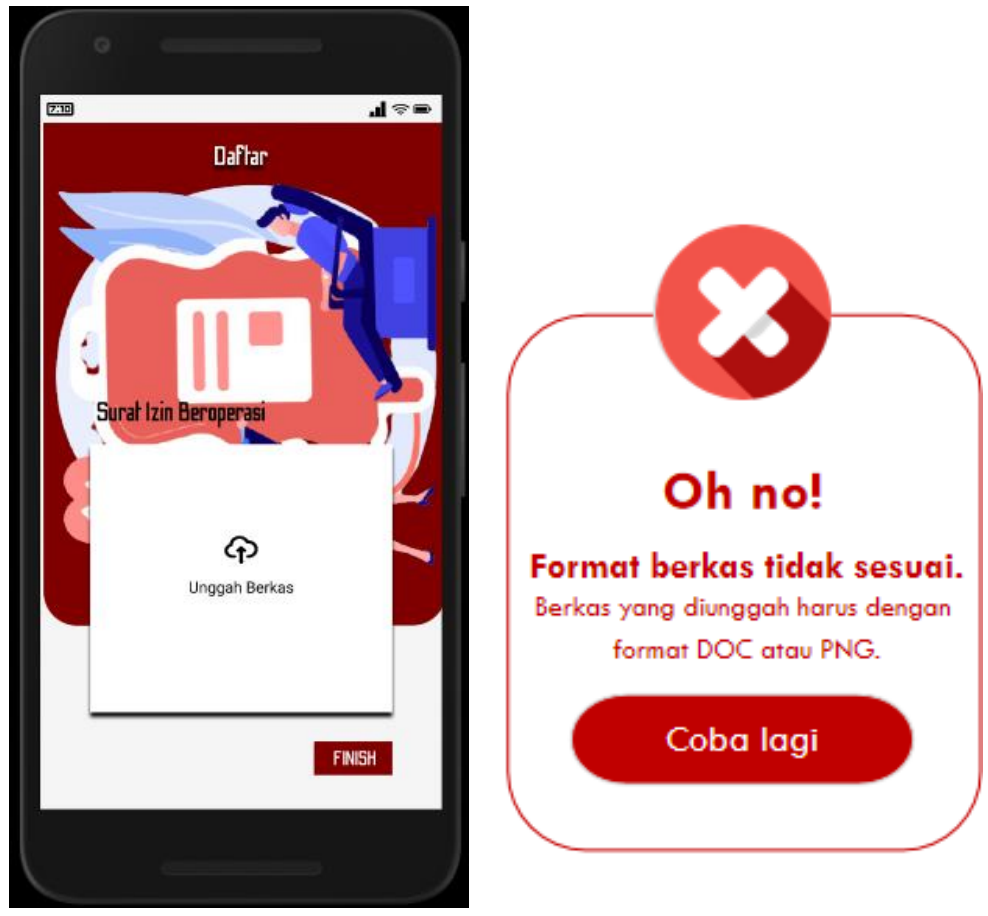

Gambar 3.1.13. 1 Notifikasi Kesalahan pada Pengunggahan Berkas

\section{m.Protection}

Protection yaitu melindungi user dari kesalahan yang umum dilakukan. Suasana nyaman perlu diciptakan oleh software engineer di antarmuka yang dibangunnya. Nyaman disini adalah suasana dimana user akan betah dan tidak menemui suasana kacau ketika user salah memasukkan data atau salah eksekusi. Seorang user akan tetap merasa nyaman ketika dia melakukan kesalahan, misal ketika user melakukan deleting atau menghapus files tanpa sengaja tidaklah menjadi kekacauan yang berarti karena misal ada recovery tools seperti undo, recycle bin, dll atau "are you sure....". Pada menu utama, terdapat menu Nama penguna Pada menu ini menyediakan aturan keluar dari akun. User bisa mengklik gambar atau nama penguna untuk keluar dari akun. 


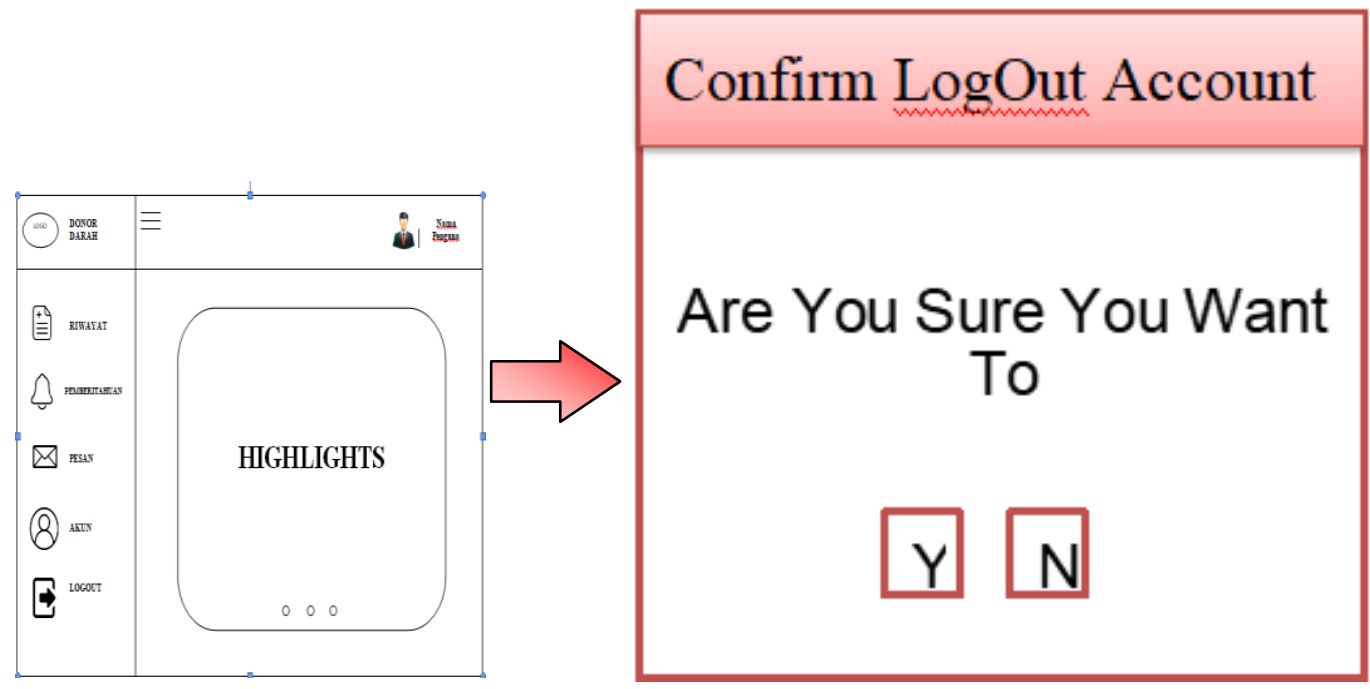

Gambar 3.1.14. 1 Ilustrasi Protection

n.Ease of Learning and ease of use

Ease of learning and Ease of Use yaitu aplikasi yang mudah dipelajari, dan harus mudah digunakan.Kemudahan dalam mengoperasikan software hanya dengan memandangi atau belajar beberapa jam saja. Kemudahan dalam memahami icon, menu-menu, alur data software, dsb. Sesudah mempelajari, user dengan mudah dan cepat menggunakan software tersebut. Jika sudah memahami tentunya akan membantu proses menjalankan sistem dengan cepat dan baik. Pada menu ini user dapat memasuki yang teretak di halaman utama user akan menuju pada halaman pusat bantuan yang berisi informasi seputar bantuan dalam pengggunaan aplikasi.

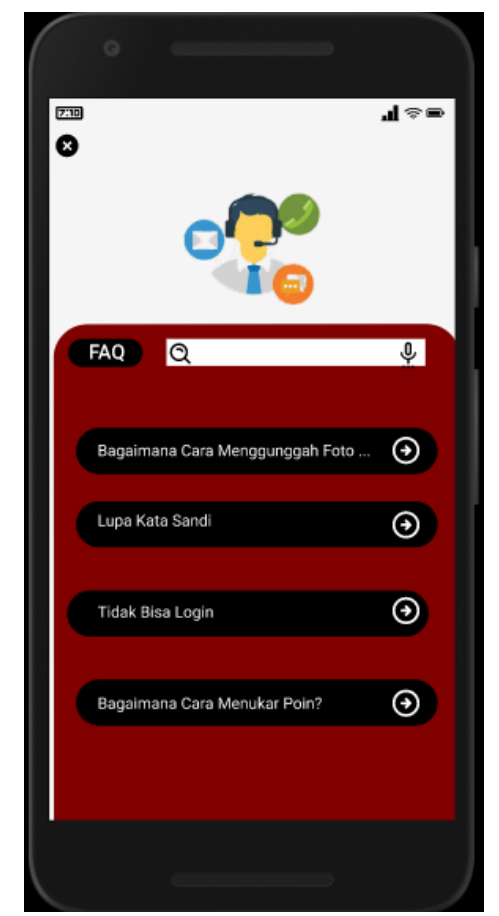




\section{o.Control}

Prinsip control ini berkenaan dengan sifat user yang mempunyai tingkat konsentrasi yang berubah-ubah. Hal itu akan sangat mengganggu proses berjalannya sistem.Kejadian salah ketik atau salah entry merupakan hal yang biasa bagi seorang user. Akan tetapi hal itu akan dapat mengganggu sistem dan akan berakibat sangat fatal karena salah memasukkan data 1 digit/1 karakter saja informasi yang dihasilkan sangat dimungkinkan salah. Oleh karena itu software engineer haruslan merancang suatu kondisi yang mampu mengatasi dan menanggulangi hal-hal seperti itu. Pada bagian ini,user menginputkan username dan password yang sesuai dengan akunnya agar dapat login ke halaman berikutnya.jika user menginput username dan password yang salah satu karakternya yang salah atau digit maka akan muncul portal jika terjadi kesalahan.

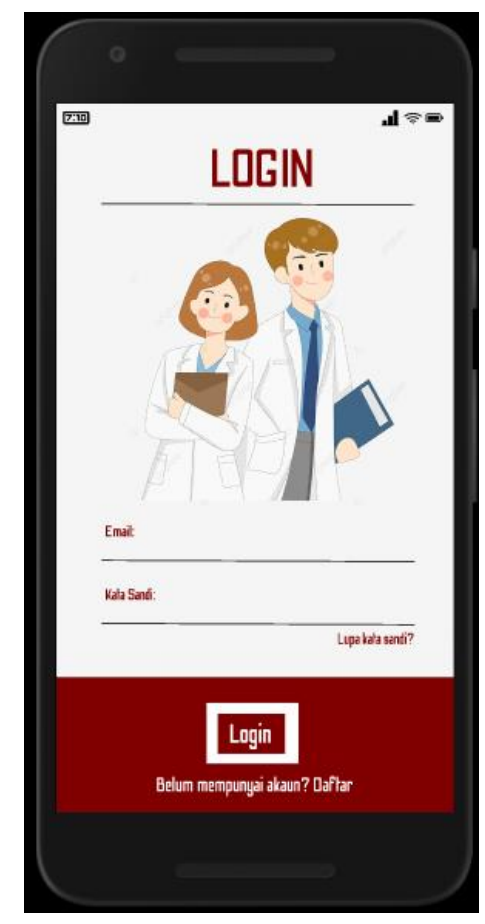

Gambar 3.1.16. 1 Control Pada Proses Login

\section{p. Use Case}

Diagram use case digunakan untuk memahami fungsi apa saja yang ada di dalam sebuah sistem dan siapa saja yang dapat menggunakan fungsi-fungsi tersebut. 


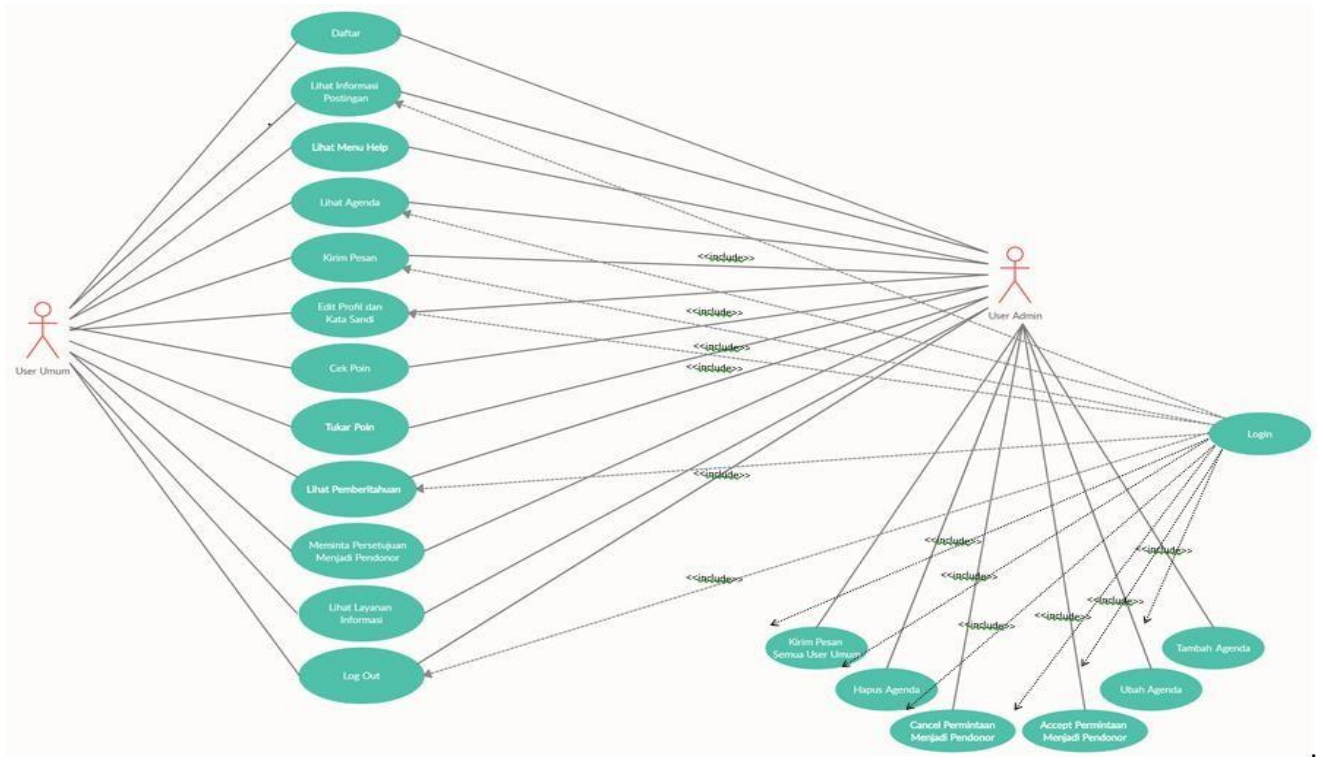

Gambar 3.2. 1 Use Case Aplikasi Donor Darah

User Aplikasi, Skenario, dan Navigasi

\section{a.User Aplikasi}

User Adalah pengguna pada layanan atau perangkat dalam sistem teknologi informasi, dimana saat kita membuat aplikasi harus mengetahui dahulu siapakah user yang akan memakai aplikasi kita. jadi dalam Aplikasi Donor darah ini sasarannya untuk User admin adalah instansi pemerintah yang memiliki surat izin untuk beroprasi yaitu PMI. Kemudian Untuk User Umun adalah user yang berasal dari masyarakat umum yang telah memiliki KTP sebagai persyaratan mendaftar akun dalam Aplikasi ini.

b.Skenario

Skenario Aplikasi Donor Darah Pada User Admin

\section{Skenario Aplikasi Donor Darah Pada User Admin}

\begin{tabular}{|l|l|l|l|l|l|}
\hline No & Task & Sub Task & Kompetensi & Deskripsi & Keterangan \\
\hline 1 & Daftar & a. Nama Instansi & - Menginputkan & Alur: Pada bagian ini & segala data \\
& & b. Alamat Instansi & informasi untuk & diarahkan untuk \\
& & c. Email & menjadi user admin & mendaftarkan \\
& & d. No.telp Instansi & & akunnya untuk & \\
& & e. Surat Izin & & menginputkan semua \\
& & f. Password & & informasi diri seperti & \\
\hline
\end{tabular}




\begin{tabular}{|c|c|c|c|c|c|}
\hline & & & & $\begin{array}{l}\text { yang tertera pada } \\
\text { halaman daftar dan } \\
\text { membuat Password } \\
\text { tujuannya agar } \\
\text { mempunyai akun } \\
\text { untuk login sebagai } \\
\text { admin. }\end{array}$ & \\
\hline 2. & Login & $\begin{array}{l}\text { a. Masukkan } \\
\text { Username } \\
\text { b. Masukkan } \\
\text { Password }\end{array}$ & 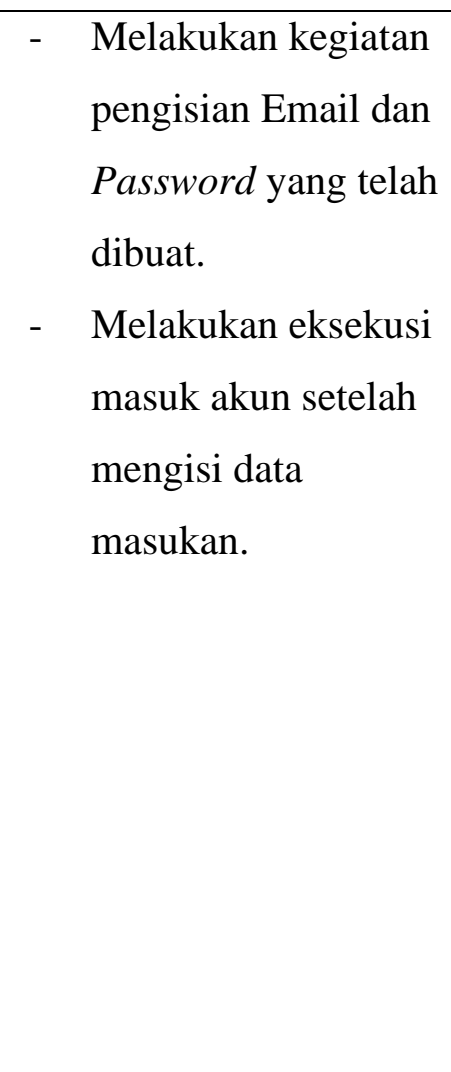 & $\begin{array}{l}\text { Alur:User admin } \\
\text { diminta untuk } \\
\text { memasukkan } \\
\text { username yang } \\
\text { berupa email yang } \\
\text { sudah di daftarkan } \\
\text { dan password yang } \\
\text { sudah dimiliki, jika } \\
\text { sudah memasukkan } \\
\text { username dan } \\
\text { password user } \\
\text { admin dapat } \\
\text { mengklik login dan } \\
\text { akan menuju } \\
\text { halaman menu. }\end{array}$ & $\begin{array}{l}\text { Ketika admin } \\
\text { lupa } \\
\text { password } \\
\text { bisa klik } \\
\text { untuk lupa } \\
\text { password } \\
\text { agar bisa } \\
\text { diatur ulang. }\end{array}$ \\
\hline 3. & $\begin{array}{l}\text { Layanan } \\
\text { Informasi }\end{array}$ & $\begin{array}{l}\text { Melihat Informasi } \\
\text { tentang Aplikasi } \\
\text { Donor Darah }\end{array}$ & $\begin{array}{l}\text {-Menampilkan Seluruh } \\
\text { Informasi Tentang } \\
\text { Program Donor Darah }\end{array}$ & $\begin{array}{l}\text { Alur: Apabila User } \\
\text { Admin Kebingungan } \\
\text { Tentang seluruh } \\
\text { Informasi Aplikasi } \\
\text { Bisa Mengklik fitur } \\
\text { layanan } \\
\text { informasi. }\end{array}$ & \\
\hline 4. & Help & Melihat Halaman & - $\quad$ Menampilkan & Alur: Pada Halaman & \\
\hline
\end{tabular}




\begin{tabular}{|c|c|c|c|c|}
\hline & & Pusat Bantuan & $\begin{array}{l}\text { Informasi pusat } \\
\text { bantuan seputar } \\
\text { bantuan penggunaan } \\
\text { aplikasi }\end{array}$ & $\begin{array}{l}\text { Utama Jika User } \\
\text { Admin masih } \\
\text { Kurang mengerti dan } \\
\text { mememerlukan } \\
\text { bantuan bisa } \\
\text { mengklik fitur help } \\
\text { dan akan tertampil } \\
\text { informasi } \\
\text { bantuan seputar } \\
\text { penggunaan aplikasi }\end{array}$ \\
\hline 5. & $\begin{array}{l}\text { Menu } \\
\text { Utama }\end{array}$ & $\begin{array}{l}\text { 1. Akun } \\
\text { 2. Agenda } \\
\text { 3. Pemberitahuan } \\
\text { 4. Laporan } \\
\text { 5. Pesan } \\
\text { 6. Logout }\end{array}$ & $\begin{array}{l}\text { - } \text { Memilih Menu } \\
\text { Utama yang ingin } \\
\text { dilakukan setelah } \\
\text { masuk di akun }\end{array}$ & $\begin{array}{l}\text { Alur: User Admin } \\
\text { yang sudah masuk, } \\
\text { dihadapkan pada } 6 \\
\text { menu Utama, yang } \\
\text { memiliki fungsi } \\
\text { berbeda-beda. } \\
\text { Pengguna hanya } \\
\text { perlu melakukan klik } \\
\text { pada setiap menu } \\
\text { yang ingin di akses. }\end{array}$ \\
\hline 6. & Akun & $\begin{array}{l}\text { Melihat } \\
\text { a. Informasi Akun } \\
\text { b. Kode QR }\end{array}$ & 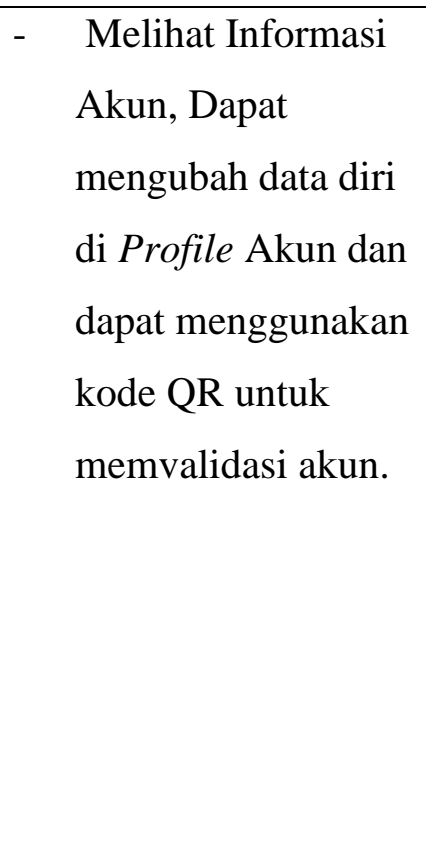 & $\begin{array}{l}\text { Alur: User Admin } \\
\text { dapat melihat } \\
\text { informasi akun yaitu } \\
\text { menampilkan } \\
\text { seluruh informasi } \\
\text { yang telah di } \\
\text { lakukan pada saat } \\
\text { proses pendaftaran, } \\
\text { User juga dapat } \\
\text { Merubah informasi } \\
\text { dari Profile akun dan } \\
\text { di dalam akun }\end{array}$ \\
\hline
\end{tabular}




\begin{tabular}{|c|c|c|c|c|}
\hline & & & & $\begin{array}{l}\text { terdapat kode QR } \\
\text { untuk memvalidasi } \\
\text { data informasi akun } \\
\text { ketika memerlukan } \\
\text { scan kode QR } \\
\text { dapat di pakai. }\end{array}$ \\
\hline 7. & $\begin{array}{l}\text { Informasi } \\
\text { Akun }\end{array}$ & Melihat Edit Profile & $\begin{array}{ll}- & \text { Mengubah } \\
& \text { Informasi dari akun }\end{array}$ & $\begin{array}{l}\text { Alur: ketika User } \\
\text { Ingin mengganti } \\
\text { Password atau } \\
\text { Username bisa klik } \\
\text { Edit Profile agar bisa } \\
\text { menggantinya. }\end{array}$ \\
\hline 8. & Agenda & Melihat Edit Agenda & 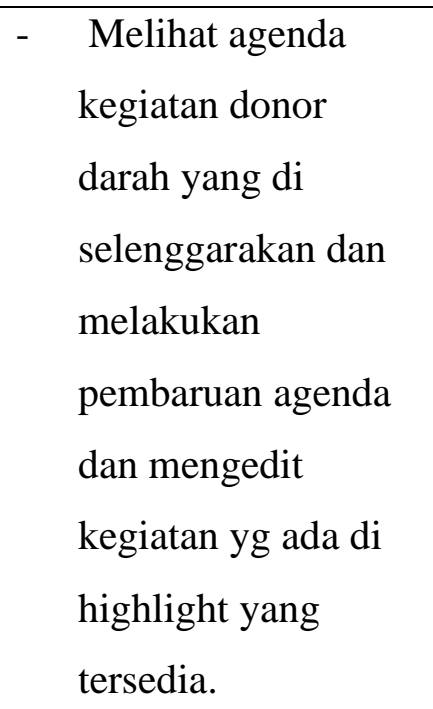 & $\begin{array}{l}\text { Alur: jadi didalam } \\
\text { fitur agenda, admin } \\
\text { dapat melihat } \\
\text { informasi kegiatan } \\
\text { donor darah sedang } \\
\text { di selenggarakan / } \\
\text { yang akan di } \\
\text { selenggarakan dan } \\
\text { dapat mengedit } \\
\text { agenda tersebut. }\end{array}$ \\
\hline 9. & $\begin{array}{l}\text { Pemberita } \\
\text { hua } \mathrm{n}\end{array}$ & $\begin{array}{l}\text { Melihat Informasi } \\
\text { user yang mendonor } \\
\text { darah }\end{array}$ & $\begin{array}{l}\text { - } \text { Melihat informasi } \\
\text { mengenai } \\
\text { permintaan user } \\
\text { umum yang } \\
\text { mendaftar pada } \\
\text { aktivitas pendonoran } \\
\text { darah }\end{array}$ & $\begin{array}{l}\text { Alur: Pada fitur } \\
\text { pemberitahuan jika } \\
\text { di klik akan menuju } \\
\text { halaman yang } \\
\text { menampilkan } \\
\text { aktivitas user umum } \\
\text { melakukan } \\
\text { pendaftaran untuk } \\
\text { pendonoran darah } \\
\text { jadi pada level ini }\end{array}$ \\
\hline
\end{tabular}




\begin{tabular}{|c|c|c|c|c|}
\hline & & & & $\begin{array}{l}\text { admin dapat } \\
\text { menerima dan } \\
\text { menolak permintaan } \\
\text { dengan cara } \\
\text {,mengklik salah satu } \\
\text { nya dan apabila } \\
\text { sudah penuh maka } \\
\text { user umum tidak } \\
\text { dapat mendaftar } \\
\text { kegiatan itu lagi } \\
\text { Karena sudah di } \\
\text { batasi } \\
\text { Kuotanya. }\end{array}$ \\
\hline 10. & Pesan & $\begin{array}{l}\text { Melihat } \\
\text { a. Pesan Masuk } \\
\text { b. Balas Pesan }\end{array}$ & 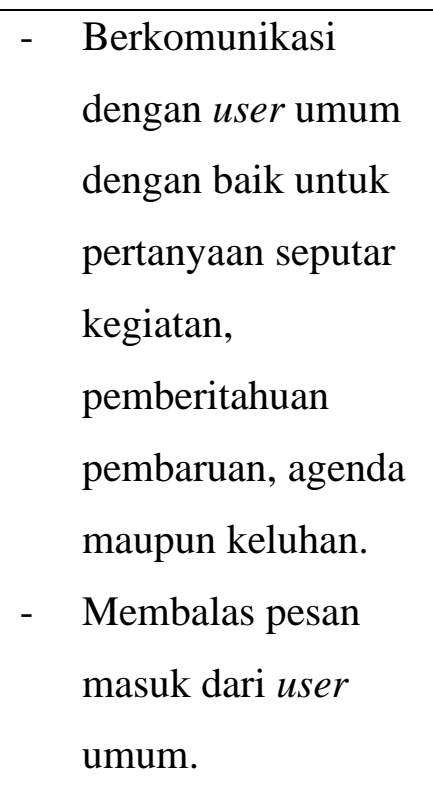 & $\begin{array}{l}\text { Alur : User Admin } \\
\text { melihat daftar pesan } \\
\text { yang masuk } \\
\text { kemudian membalas } \\
\text { pesan satu persatu } \\
\text { dengan mengetikkan } \\
\text { pesan balasan, } \\
\text { kemudian klik kirim } \\
\text { untuk mengirim } \\
\text { balasan. }\end{array}$ \\
\hline 11. & Logout & $\begin{array}{l}\text { Keluar dari Akun } \\
\text { User Admin }\end{array}$ & 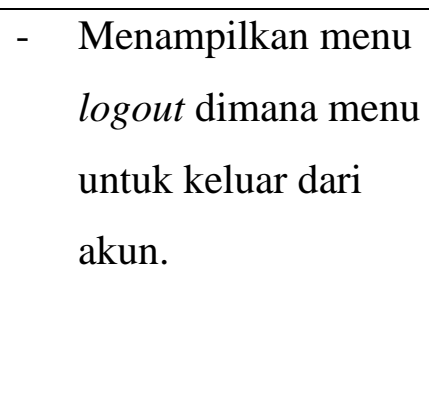 & $\begin{array}{l}\text { Alur: User Admin } \\
\text { jika klik menu } \\
\text { logout akan menuju } \\
\text { kembali pada } \\
\text { halaman utama } \\
\text { karena telah }\end{array}$ \\
\hline
\end{tabular}




\begin{tabular}{|l|l|l|l|l|l|}
\hline & & & keluar dari akun. & \\
\hline
\end{tabular}

Table 1 Skenario Aplikasi Donor Darah Pada User Admin

Skenario Aplikasi Pada User Umum

\begin{tabular}{|c|c|c|c|c|c|}
\hline \multicolumn{6}{|c|}{ Skenario Aplikasi Donor Darah Pada User Admin } \\
\hline No & Task & Sub Task & Kompetensi & Deskripsi & Keterangan \\
\hline 1 & Daftar & $\begin{array}{l}\text { a. Nama Lengkap } \\
\text { b. No. hp } \\
\text { c. Alamat } \\
\text { d. Email } \\
\text { e. Ktp } \\
\text { f. Surat Hasil Cek } \\
\text { g. Golongan darah }\end{array}$ & $\begin{array}{l}\text { - } \text { Menginputkan } \\
\text { segala data } \\
\text { informasi untuk } \\
\text { menjadi User } \\
\text { Umum }\end{array}$ & $\begin{array}{l}\text { Alur: Pada bagian ini } \\
\text { user umum di } \\
\text { arahkan untuk } \\
\text { mendaftarkan } \\
\text { akunnya untuk } \\
\text { menginputkan semua } \\
\text { informasi diri seperti } \\
\text { yang tertera pada } \\
\text { halaman daftar,dan } \\
\text { membuat Password } \\
\text { tujuanya agar } \\
\text { mempunyai akun } \\
\text { untuk login. }\end{array}$ & \\
\hline 2. & Login & $\begin{array}{l}\text { c. Masukkan } \\
\text { Username } \\
\text { d. Masukkan } \\
\text { Password }\end{array}$ & 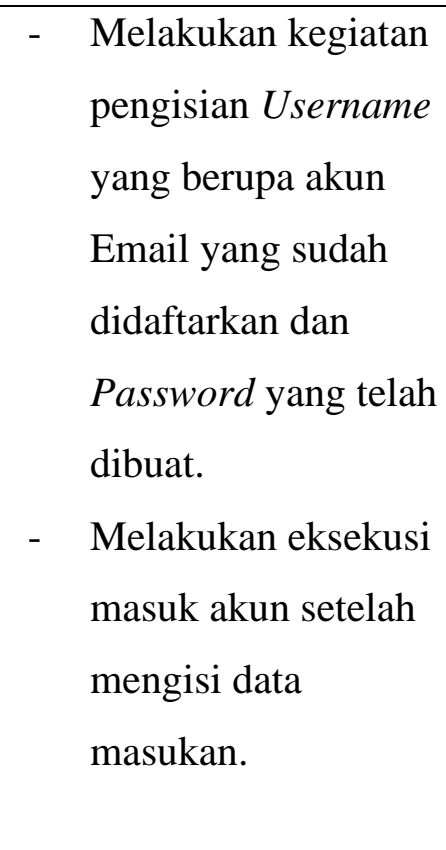 & $\begin{array}{l}\text { Alur : User Umum } \\
\text { diminta untuk } \\
\text { memasukkan } \\
\text { Username yang } \\
\text { berupa email yang } \\
\text { sudah di daftarakan } \\
\text { dan Password yang } \\
\text { sudah dimiliki, jika } \\
\text { sudah memasukkan } \\
\text { Username dan } \\
\text { Password User } \\
\text { dapat mengklik login }\end{array}$ & $\begin{array}{l}\text { Ketika admin } \\
\text { lupa } \\
\text { password } \\
\text { bisa klik } \\
\text { untuk lupa } \\
\text { password } \\
\text { agar bisa } \\
\text { diatur ulang. }\end{array}$ \\
\hline
\end{tabular}




\begin{tabular}{|c|c|c|c|c|}
\hline & & & & $\begin{array}{l}\text { dan akan menuju } \\
\text { pada halaman menu } \\
\text { utama. }\end{array}$ \\
\hline 3. & $\begin{array}{l}\text { Layanan } \\
\text { Informasi }\end{array}$ & $\begin{array}{l}\text { Melihat Informasi } \\
\text { tentang Aplikasi } \\
\text { Donor Darah }\end{array}$ & $\begin{array}{l}\text { Menampilkan } \\
\text { Seluruh Informasi } \\
\text { Tentang Program } \\
\text { Donor Darah }\end{array}$ & $\begin{array}{l}\text { Alur: Apabila User } \\
\text { Admin Kebingungan } \\
\text { Tentang seluruh } \\
\text { Informasi Aplikasi } \\
\text { Bisa Mengklik fitur } \\
\text { layanan } \\
\text { informasi. }\end{array}$ \\
\hline 4. & Help & $\begin{array}{l}\text { Melihat Halaman } \\
\text { Pusat Bantuan }\end{array}$ & 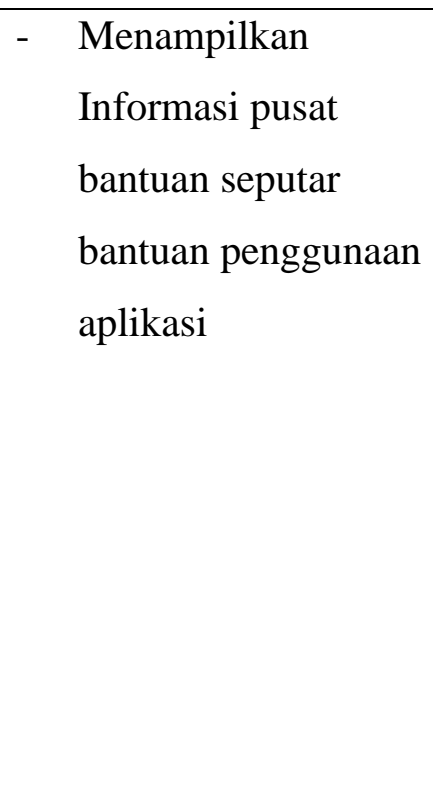 & $\begin{array}{l}\text { Alur: Pada Halaman } \\
\text { Utama Jika User } \\
\text { Umum masih } \\
\text { Kurang mengerti dan } \\
\text { mememerlukan } \\
\text { bantuan bisa } \\
\text { mengklik fitur help } \\
\text { dan akan tertampil } \\
\text { informasi bantuan } \\
\text { seputar penggunaan } \\
\text { aplikasi }\end{array}$ \\
\hline 5. & $\begin{array}{l}\text { Menu } \\
\text { Utama }\end{array}$ & $\begin{array}{l}\text { 1. Akun } \\
\text { 2. Agenda } \\
\text { 3. Pemberitahuan } \\
\text { 4. Laporan } \\
\text { 5. Pesan } \\
\text { 6. Logout }\end{array}$ & $\begin{array}{ll}- & \text { Memilih Menu } \\
\text { Utama yang ingin } \\
\text { dilakukan setelah } \\
\text { masuk di akun }\end{array}$ & $\begin{array}{l}\text { Alur: User Umum } \\
\text { yang sudah masuk, } \\
\text { dihadapkan pada } 5 \\
\text { menu Utama, yang } \\
\text { memiliki fungsi } \\
\text { berbeda-beda. } \\
\text { Pengguna hanya } \\
\text { perlu melakukan klik } \\
\text { pada setiap menu } \\
\text { yang ingin di akses. }\end{array}$ \\
\hline
\end{tabular}




\begin{tabular}{|c|c|c|c|c|}
\hline 6. & Akun & $\begin{array}{l}\text { Melihat } \\
\text { a. Informasi Akun } \\
\text { b. Kode QR } \\
\text { c. Cek Poin }\end{array}$ & $\begin{array}{l}\text { Melihat Informasi } \\
\text { Akun, Dapat } \\
\text { mengubah data diri } \\
\text { di Profile Akun dan } \\
\text { dapat menggunakan } \\
\text { kode QR untuk } \\
\text { memvalidasi akun, } \\
\text { serta dapat } \\
\text { mengecek poin } \\
\text { didapat }\end{array}$ & $\begin{array}{l}\text { Alur: Jadi dalam } \\
\text { akun terdapat } 3 \\
\text { pilihan fitur yaitu } \\
\text { informasi akun } \\
\text { untuk menampilkan } \\
\text { seluruh informasi } \\
\text { data yang telah di } \\
\text { inputkan pada } \\
\text { saat proses } \\
\text { Pendaftaran User } \\
\text { juga dapat Merubah } \\
\text { informasi akun, dan } \\
\text { Kode QR berfungsi } \\
\text { untuk mempermudah } \\
\text { memvalidasi data } \\
\text { informasi akun } \\
\text { ketika memerlukan } \\
\text { scan kode QR dapat } \\
\text { dipakai. }\end{array}$ \\
\hline 7. & $\begin{array}{l}\text { Informasi } \\
\text { Akun }\end{array}$ & Melihat Edit Profile & $\begin{array}{ll}\text { - } & \text { Mengubah } \\
& \text { Informasi dari akun }\end{array}$ & $\begin{array}{l}\text { Alur: ketika User } \\
\text { Ingin mengganti } \\
\text { Password atau } \\
\text { Username bisa klik } \\
\text { Edit Profile agar bisa } \\
\text { menggantinya. }\end{array}$ \\
\hline 8. & Cek Poin & Melihat Tukar Poin & $\begin{array}{ll}\text { - } & \text { Menukar Poin yang } \\
\text { telah di dapat }\end{array}$ & $\begin{array}{l}\text { Alur: Ketika User } \\
\text { umum Telah } \\
\text { melalukan } \\
\text { pendonoran darah } \\
\text { dan otomatis } \\
\text { mendapat poin, } \\
\text { kemudian } \text { user ingin }\end{array}$ \\
\hline
\end{tabular}




\begin{tabular}{|c|c|c|c|c|}
\hline & & & & $\begin{array}{l}\text { menukarkan } \\
\text { poin tersebut dapat } \\
\text { klik fitur tukar poin } \\
\text { dan di arahkan untuk } \\
\text { menginputkan } \\
\text { nomor rekening } \\
\text { kedalam sistem. }\end{array}$ \\
\hline 9. & $\begin{array}{l}\text { Pemberita } \\
\text { hua } \mathrm{n}\end{array}$ & $\begin{array}{l}\text { Menampilkan } \\
\text { Pemberitahuan } \\
\text { tentang aktivitas } \\
\text { terbaru di beranda }\end{array}$ & $\begin{array}{l}\text { - Menampilkan } \\
\text { aktivitas Terbaru } \\
\text { yang di upload oleh } \\
\text { Admin }\end{array}$ & $\begin{array}{l}\text { Alur: Jadi Saat user } \\
\text { sedang tidak melihat } \\
\text { isi beranda, namun } \\
\text { ada aktivitas yang } \\
\text { berlangsung, } \\
\text { notifikasi itu akan } \\
\text { masuk di } \\
\text { pemberitahuan dan } \\
\text { ketika user } \\
\text { mendaftar dan } \\
\text { pendaftaran sudah di } \\
\text { setujui/tidak oleh } \\
\text { admin notifikasi itu } \\
\text { akan muncul di } \\
\text { Pemberitahuan. }\end{array}$ \\
\hline 10. & Riwayat & $\begin{array}{l}\text { Melihat } \\
\text { a. Aktivitas } \\
\text { b. Transaksi }\end{array}$ & $\begin{array}{l}\text { Melihat aktivitas } \\
\text { dan transaksi yang } \\
\text { telah di lakukan. }\end{array}$ & $\begin{array}{l}\text { Alur: Ketika User } \\
\text { Umum memilih } \\
\text { aktivitas maka akan } \\
\text { terlihat informasi- } \\
\text { informasi tentang } \\
\text { kegiatan donor darah } \\
\text { yang telah di } \\
\text { lakukan, lalu jika } \\
\text { user umum memilih } \\
\text { transaksi maka akan }\end{array}$ \\
\hline
\end{tabular}




\begin{tabular}{|c|c|c|c|c|}
\hline & & & & $\begin{array}{l}\text { tertampil informasi } \\
\text { tarnsaksi penukaran } \\
\text { poin yang telah di } \\
\text { lakukan. }\end{array}$ \\
\hline 11. & Pesan & $\begin{array}{l}\text { Melihat } \\
\text { a. Pesan Masuk } \\
\text { b. Balas pesan }\end{array}$ & 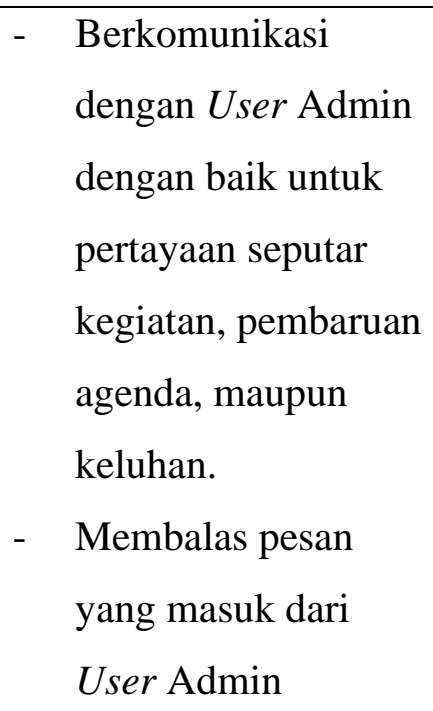 & $\begin{array}{l}\text { Alur: User Umun } \\
\text { melihat daftar pesan } \\
\text { yang masuk } \\
\text { kemudian membalas } \\
\text { pesan dengan } \\
\text { mengetikkan pesan } \\
\text { balasan, kemudian } \\
\text { klik kirim untuk } \\
\text { mengirim balasan } \\
\text { kepada user admin. }\end{array}$ \\
\hline 12. & Logout & $\begin{array}{l}\text { Keluar dari Akun } \\
\text { User Umum }\end{array}$ & $\begin{array}{l}\text { - Menampilkan menu } \\
\text { logout dimana menu } \\
\text { untuk keluar dari } \\
\text { akun. }\end{array}$ & $\begin{array}{l}\text { Alur: User Umum } \\
\text { jika klik menu } \\
\text { logout akan menuju } \\
\text { kembali pada } \\
\text { halaman utama } \\
\text { karena telah } \\
\text { keluar dari akun. }\end{array}$ \\
\hline
\end{tabular}

\section{Table 2 Skenario Aplikasi Pada User Umum}

c.Navigasi

Dalam perancangan aplikasi ini,model navigasi yang digunakan adalah Model Navigasi Hirarki.Makna secara umum navigasi adalah petunjuk posisi dan arah perjalanan. Navigasi berfungsi untuk berpindah dari satu halaman ke halaman yang lain pada suatu aplikasi berbasis web, dan juga memberikan informasi lokasi halaman yang sedang dibuka. Berikut adalah model Navigasi Hirarki dari Perancangan Aplikasi “ Donor Darah “: 


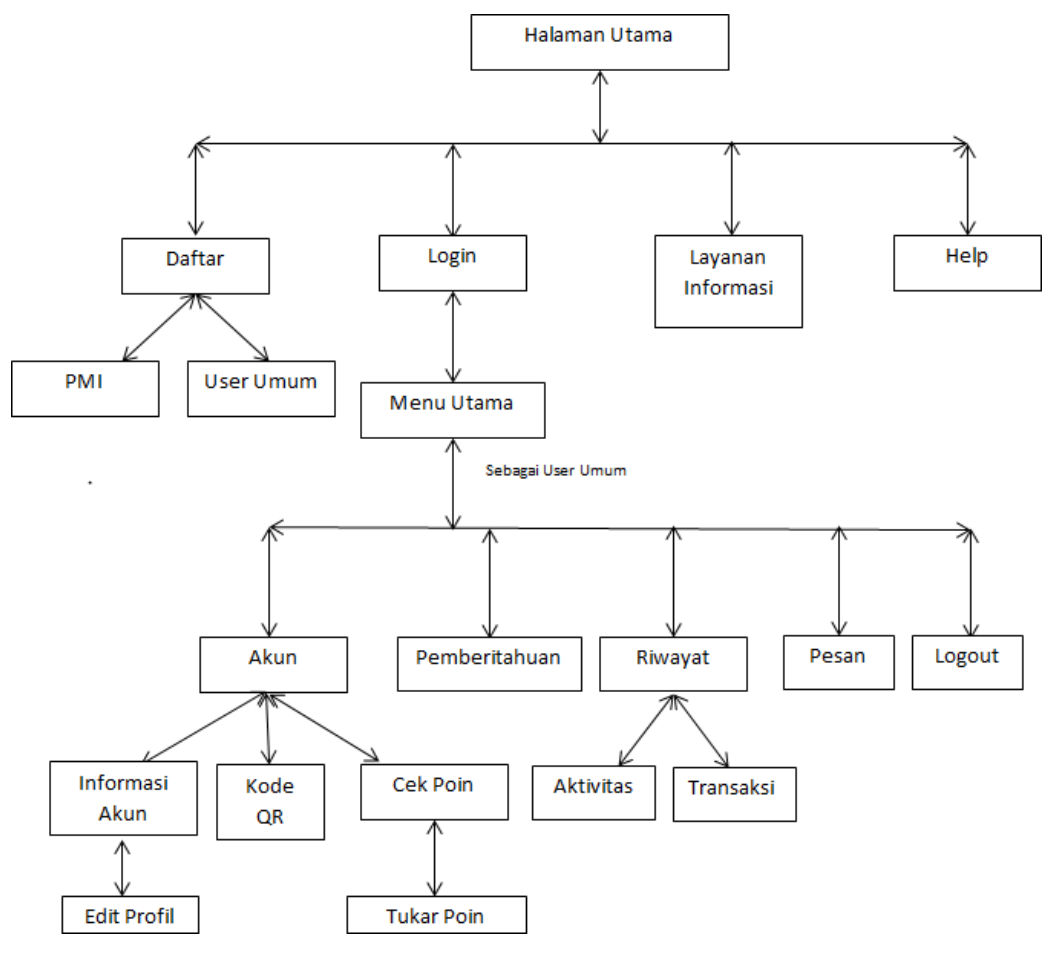

Gambar 3.3.3. 1 Navigasi User Umum

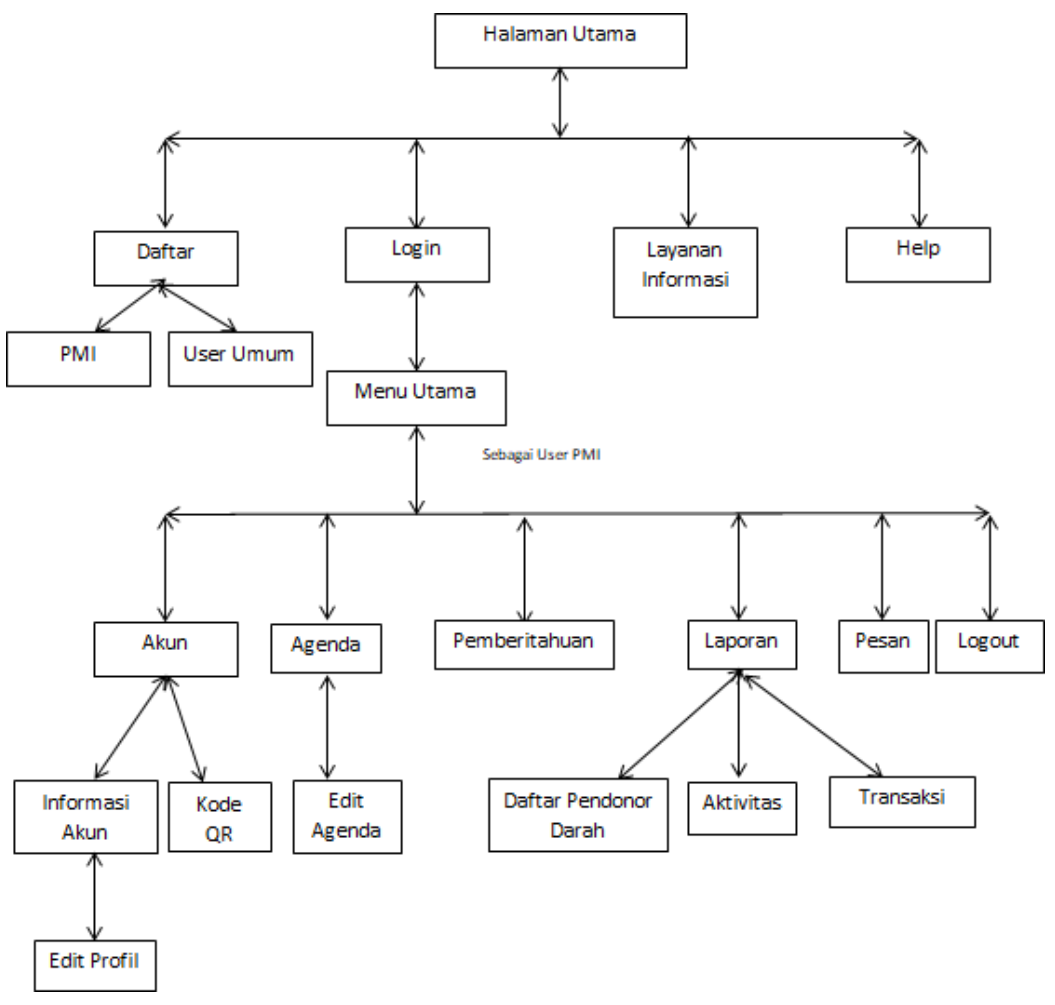

Gambar 3.3.3. 2 Navigasi User PMI

Penjelasan dari model Navigasi Hirarki dalam Perancangan Aplikasi “ Donor Darah " : 
Navigasi untuk User Umum:

1. Halaman Utama : Pada saat pertama kali mengakses aplikasi, sistem akan masuk pada halaman utama yang mana terdapat beberapa menu pada halaman utama ini.

2. Daftar : Jika klik "Daftar" artinya user ingin mendaftarkan akun. Dengan user terlebih dahulu memilih jenis kategori pendaftaran yaitu daftar sebagai instansi PMI atau User Umum(masyarakat).

3. Daftar (PMI): Jika user merupakan instansi PMI, proses daftar dapat mengklik pilihan "PMI'kemudian user diarahkan pada halaman untuk menginputkan segala data informasi sesuai yang tertera pada halaman daftar.

4. Daftar (User Umum) : Jika user merupakan masyarakat umum, proses daftar dapat mengklik pilihan "User Umum" kemudian user diarahkan pada halaman untuk menginputkan segala data informasi sesuai yang tertera pada halaman daftar.

5. Login : Jika kilik "Login" akan menuju pada halaman menu utama. Pada bagian ini,user menginputkan username dan password yang sesuai dengan akunnya agar dapat login ke halaman berikutnya.

6. Layanan Informasi: Jika klik "Layanan Informasi" akan menuju halaman yang menampilkan seluruh informasi terkait program aplikasi.

7. Help : Jika klik "Help" user akan menuju pada halaman pusat bantuan yang berisi informasi seputar bantuan dalam pengggunaan aplikasi.

8. Menu Utama : Akan menuju ke halaman beranda yang terdapat menu- menu di dalam halaman tersebut. Pada menu utama ini juga akan menampilkan informasi mengenai kegiatan donor darah yang akan diselenggarakan sehingga bagi user yang ingin berpatisipasi dapat memilih kegiatan sesuai dengan pilihannya.

9. Akun : Akan menampilkan sub-sub menu yang terdapat didalamnya. Bagian ini digunakan untuk melihat sub menu informasi akun,kode QR dan cek poin yang diperoleh.

10. Informasi Akun : Jika klik "Informasi Akun" akan menampilkan seluruh informasi data yang telah diinputkan pada saat proses pendaftaran.

11. Edit Profil : Jika klik "Edit Profil" akan menuju halaman untuk melakukan pembaruhan data yang ingin diubah.

12. Cek Poin : Jika klik "Cek Poin" akan menuju halaman yang menampilkan informasi poin yang telah dikumpulkan dalam kegiatan donor darah yang telah dilakukan.

13. Tukar Poin : Jika klik "Tukar Poin" akan menuju pada halaman untuk melakukan proses 
transaksi penukaran poin dengan terlebih dahulu user menginputkan nomor rekening kedalam sistem.

14. Pemberitahuan : Jika klik "Pemberitahuan" akan menuju halaman yang menampilkan informasi-informasi terbaru tentang aktifitas pendonoran darah, informasi tentang diterimanya maupun ditolaknya user sebagai calon pendonor darah dalam sebuah kegiatan yang diikutinya serta transaksi penukaran poin yang dilakukan.

15. Riwayat : Akan menampilkan sub-sub menu yang terdapat didalamnya. Bagian ini digunakan untuk melihat sub menu berupa riwayat aktivitas dan transaksi yang telah berlangsung.

16. Riwayat( Aktivitas): Jika klik "Aktivitas" akan menuju halaman yang menampilkan informasi- tentang kegiatan donor darah yang telah diikuti.

17. Riwayat( Transaksi): Jika klik "Transaksi" akan menuju halaman yang menampilkan informasi tentang transaksi penukaran poin yang telah dilakukan.

18. Pesan : Jika klik "Pesan" akan menuju halaman pesan.

19. Logout: Jika klik "Logout” akan menuju kembali pada Halaman Utama.

Navigasi untuk User PMI:

1. Halaman Utama : Pada saat pertama kali mengakses aplikasi, sistem akan masuk pada halaman utama yang mana terdapat beberapa menu pada halaman utama ini.

2. Daftar : Jika klik "Daftar" artinya user ingin mendaftarkan akun. Pada bagian ini,user diarahkan pada halaman untuk menginputkan segala data informasi sesuai yang tertera pada halaman daftar.

3. Daftar : Jika klik "Daftar" artinya user ingin mendaftarkan akun. Dengan user terlebih dahulu memilih jenis kategori pendaftaran yaitu daftar sebagai instansi PMI atau User Umum(masyarakat).

4. Daftar (PMI): Jika user merupakan institusi PMI, proses daftar dapat mengklik pilihan "PMI"kemudian user diarahkan pada halaman untuk menginputkan segala data informasi sesuai yang tertera pada halaman daftar.

5. Daftar (User Umum) : Jika user merupakan masyarakat umum, proses daftar dapat mengklik pilihan "User Umum” kemudian user diarahkan pada halaman untuk menginputkan segala data informasi sesuai yang tertera pada halaman daftar.

6. Login : Jika kilik "Login" akan menuju pada halaman menu utama. Pada bagian ini,user menginputkan username dan password yang sesuai dengan akunnya agar dapat login ke 
halaman berikutnya.

7. Layanan Informasi: Jika klik "Layanan Informasi" akan menuju halaman yang menampilkan seluruh informasi terkait program aplikasi.

8. Help : Jika klik "Help" user akan menuju pada halaman pusat bantuan yang berisi informasi seputar bantuan dalam pengggunaan aplikasi.

9. Menu Utama : Akan menuju ke halaman beranda yang terdapat menu- menu di dalam halaman tersebut. Pada menu utama ini juga akan menampilkan informasi mengenai kegiatan donor darah yang akan diselenggarakan.

10. Laporan : Akan menampilkan sub-sub menu yang terdapat di dalamnya antara lain sub menu laporan mengenai daftar pendonor darah, kegiatan yang telah dilakukan dan laporan transaksi.

11. Daftar Pendonor Darah : Jika klik "Daftar Pendonor Darah" akan menuju pada halaman yang menampilkan laporan seluruh daftar pendonor darah yang mengikuti kegiatan donor darah.

12. Aktivitas : Jika klik "Aktivitas" akan menuju halaman yang menampilkan informasi tentang aktifitas pendonoran darah yang telah dilakukan.

13. Transaksi : Jika klik "Transaksi" akan menuju pada halaman yang menampilkan laporan transaksi penukaran poin yang dilakukan oleh akun pendaftar donor darah.

14. Akun : Akan menampilkan sub-sub menu yang terdapat didalamnya. Bagian ini digunakan untuk melihat sub menu informasi akun dan kode QR.

15. Informasi Akun : Jika klik "Informasi Akun" akan menampilkan seluruh informasi data yang telah diinputkan pada saat proses pendaftaran.

16. Edit Profil : Jika klik "Edit Profil" akan menuju halaman untuk melakukan pembaruhan data yang ingin diubah.

17. Agenda : Jika klik "Agenda" akan menuju halaman yang menampilkan informasitentang aktivitas pendonoran darah yang akan diselenggarakan.

18. Edit Agenda : Jika klik "Edit Agenda" akan menuju halaman untuk melakukan pembaruhan agenda pendonoran darah.

19. Pemberitahuan : Jika klik "Pemberitahuan" akan menuju halaman yang menampilkan informasi mengenai permintaan akun-akun user umum yang mendaftar dalam aktifitas pendonoran darah. Pada bagian ini juga,user(admin) dapat menerima permintaan dari user lainnya yang mendaftar sebagai pendonor darah dalam kegiatan yang diadakan. 
20. Pesan : Jika klik "Pesan" akan menuju halaman pesan.

21. Logout: Jika klik "Logout” akan menuju kembali pada Halaman Utama.

Lembar Kerja Tampilan dan Jaringan Semantik

a.Lembar Kerja Tampilan

Langkah-langkah yang penulis rekomendasikan sebelummerancang layar sesuai dengan konsep IMK diantaranya:

1.Setiap pekerjaan perlu dilakukan dokumentasi, sehingga apabila ingin mengubah rancanganatau menyesuaikan rancangan dengan keinginan user, perancang hanya memerlukan penyesuaian saja.Dokumentasi dapat dibuat dengan sketsa pada kertas, menggunakan peranti prototype GUI,membuat teks yang menjelaskan kaitanantara jendela satu dengan lainnyaatau menggunakan perantiCASE (Computer-Aided Software Engineering).

2.Pendekatan tehadap pengguna, yaitu pendekatan secara user-centered designatau pendekatan user design approach.

3.Mempelajari perbedaan konsep dan keinginan dari masing-masing pengguna.

4.Merencanakan rancangan agar layar lebih konsisten, usability universal,Memberikan umpan balik yang inofatif, ragam dialog yang baik, penanganan kesalahan yang baikdan pengendalian aksi yang mudah dan mengurangi beban ingatan pengguna.

Sedangkan urutan untuk merancang antar muka, yaitu:

1.Pemilihan ragam dialog.Pilihlah ragam dialog yang cocok untuk tugas pengguna.

2.Perancangan struktur dialog.Tahap ini adalahmelakukan analisis tugas dan menentukan model keinginan penggunauntuk membentuk struktur dialog yang sesuai.

3.Perancangan format pesan.Tata letak tampilan dan keterangan tekstual secara terinci harus mendapat perhatian lebih.

4.Perancangan penanganan kesalahan.Bentuk-bentuk penanganan kesalahan dapat dilakuakan, diantranya validasi pemasukan data, proteksi pengguna, pemulihan dari kesalahan, penampilan pesan salah yang tepat dan sesuai dengan kesalahan yang terjadi pada waktu itu.

5.Perancangan struktur data.Menentukan struktur data yang dapat digunakan untuk menyajikan dan mendukung fungsionalitas komponen-komponen antar mukayang diperlukan.Pada bagian awal telah dijelaskan dokumentasi harus dibuat dalam perancangan layar,oleh karena itu penulis memberi solusiyang mudah sesuai dengan prinsipIMKyaitu dengan Perancang 
seharusnya membuat dokumentasi akan bentuk-bentuk tampilan yang akan diimplementasikan. Peranti bantu sederhana yang dapat digunakan misalnya adalah lembar kerja tampilan/LKT (screen design work sheet).

\section{Berikut LKT dari aplikasi Donor Darah}

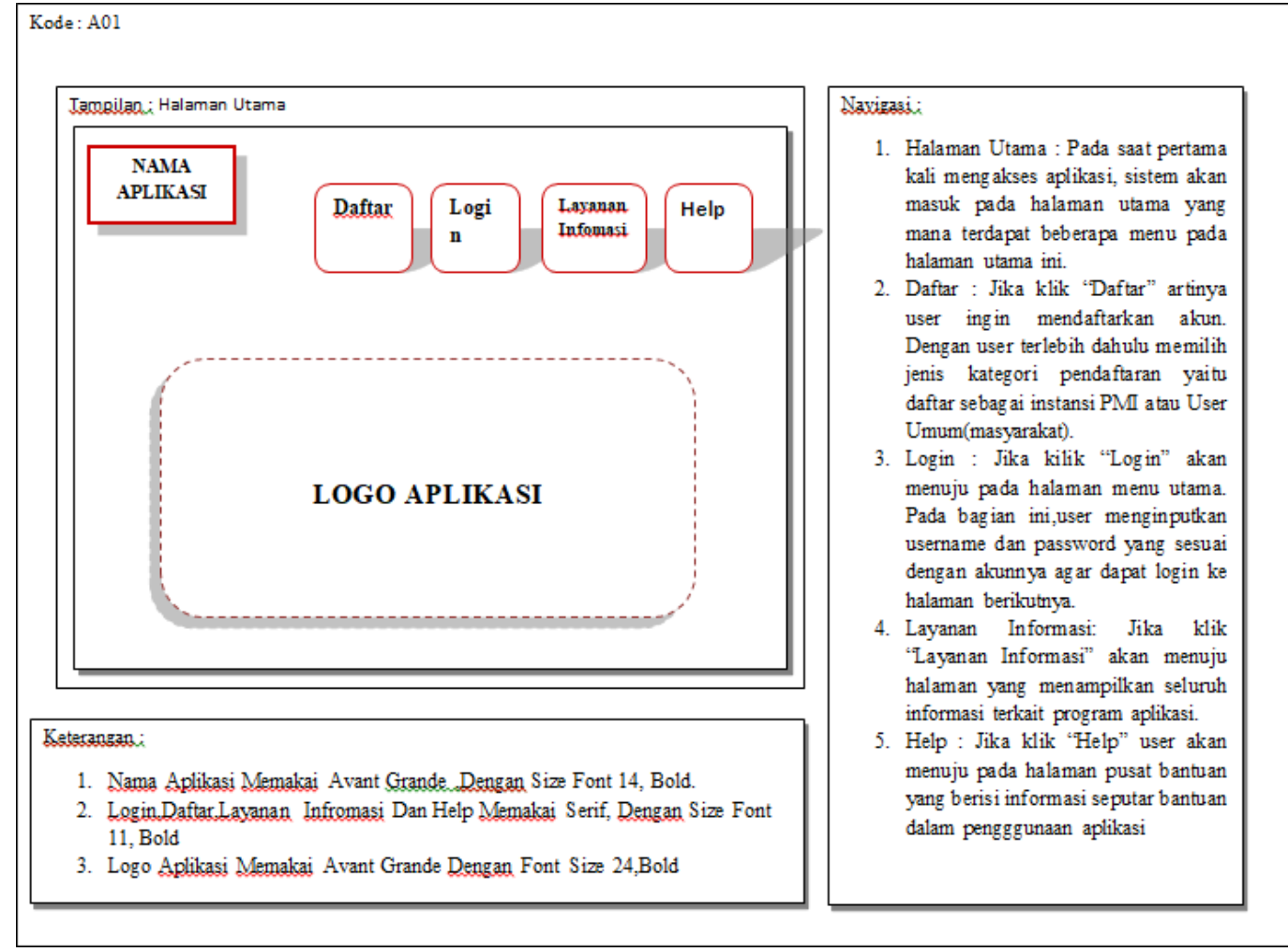

Gambar 3.5.1. 1 LKT Halaman Utama 


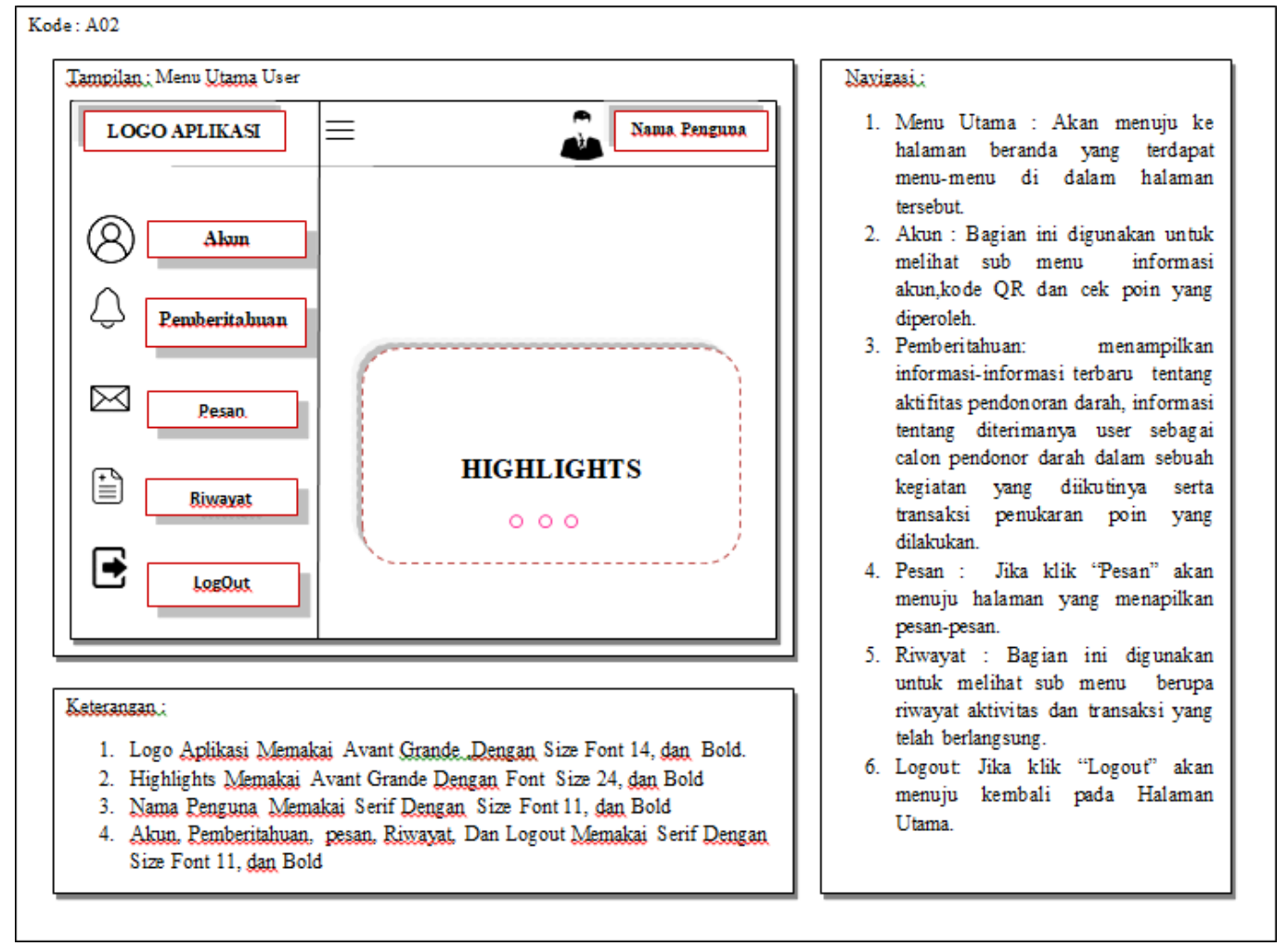

\section{Gambar 3.5.1. 2 LKT Menu Utama User}

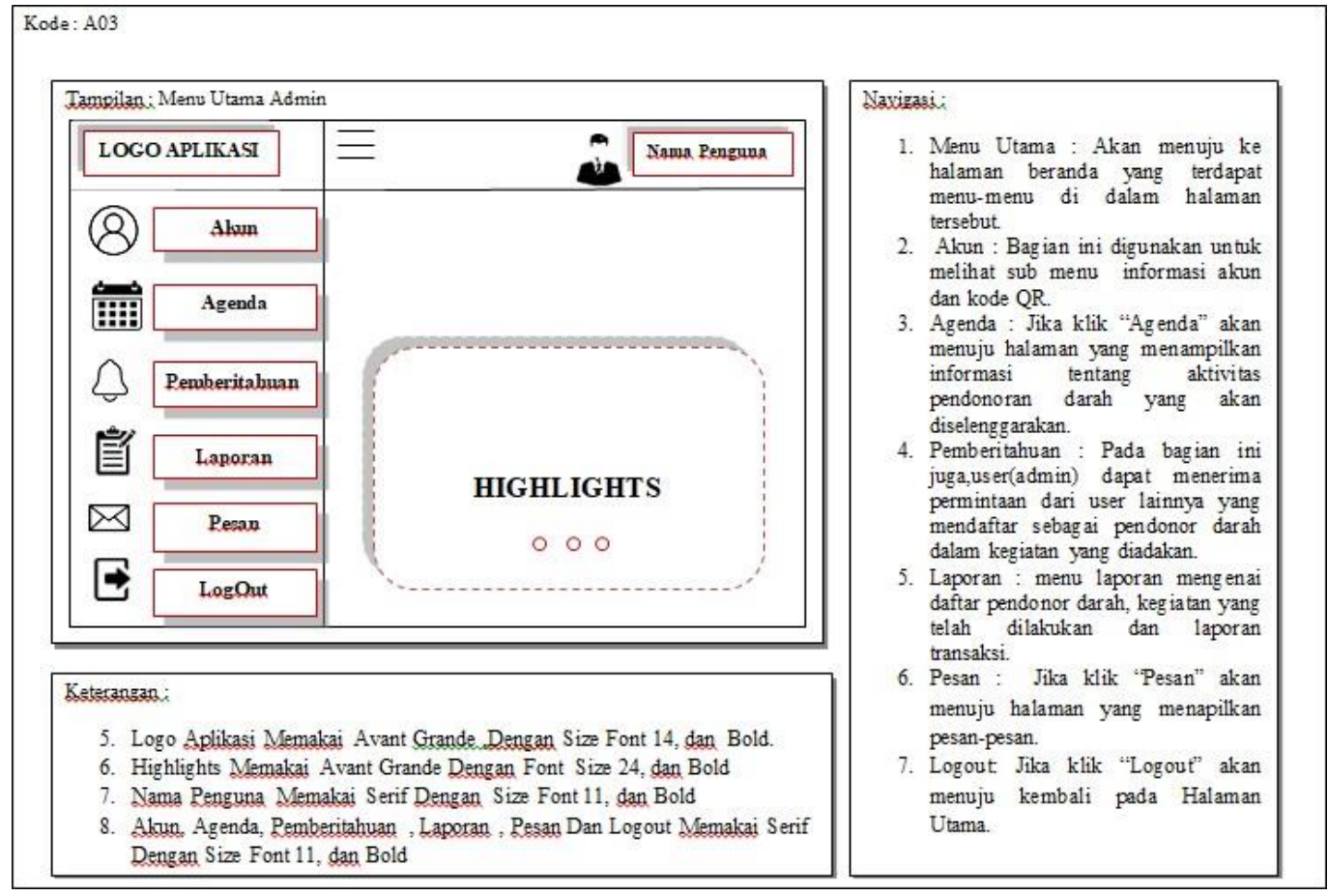

Gambar 3.5.1. 3 LKT Menu Utama Admin 


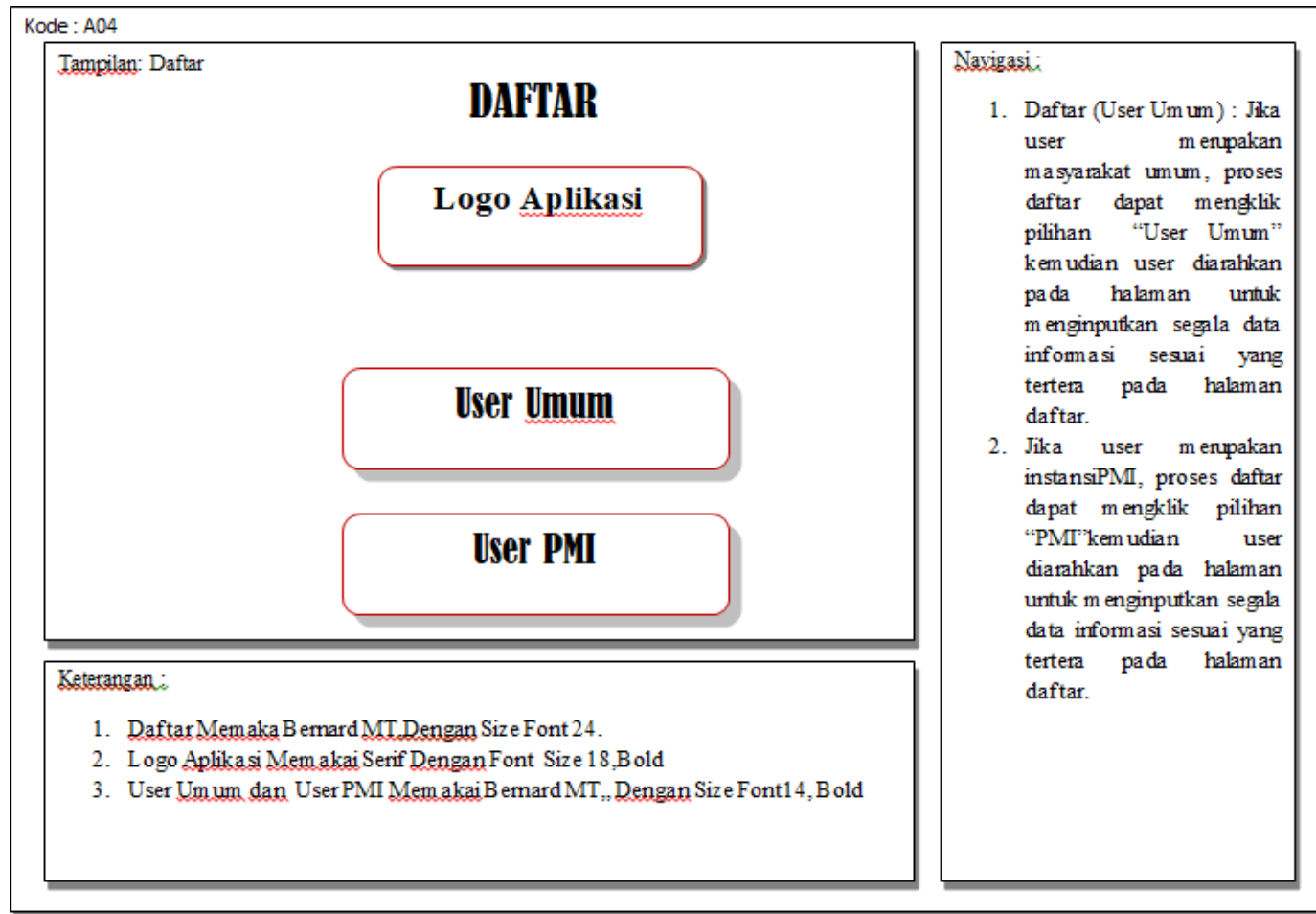

Gambar 3.5.1. 4 LKT Daftar

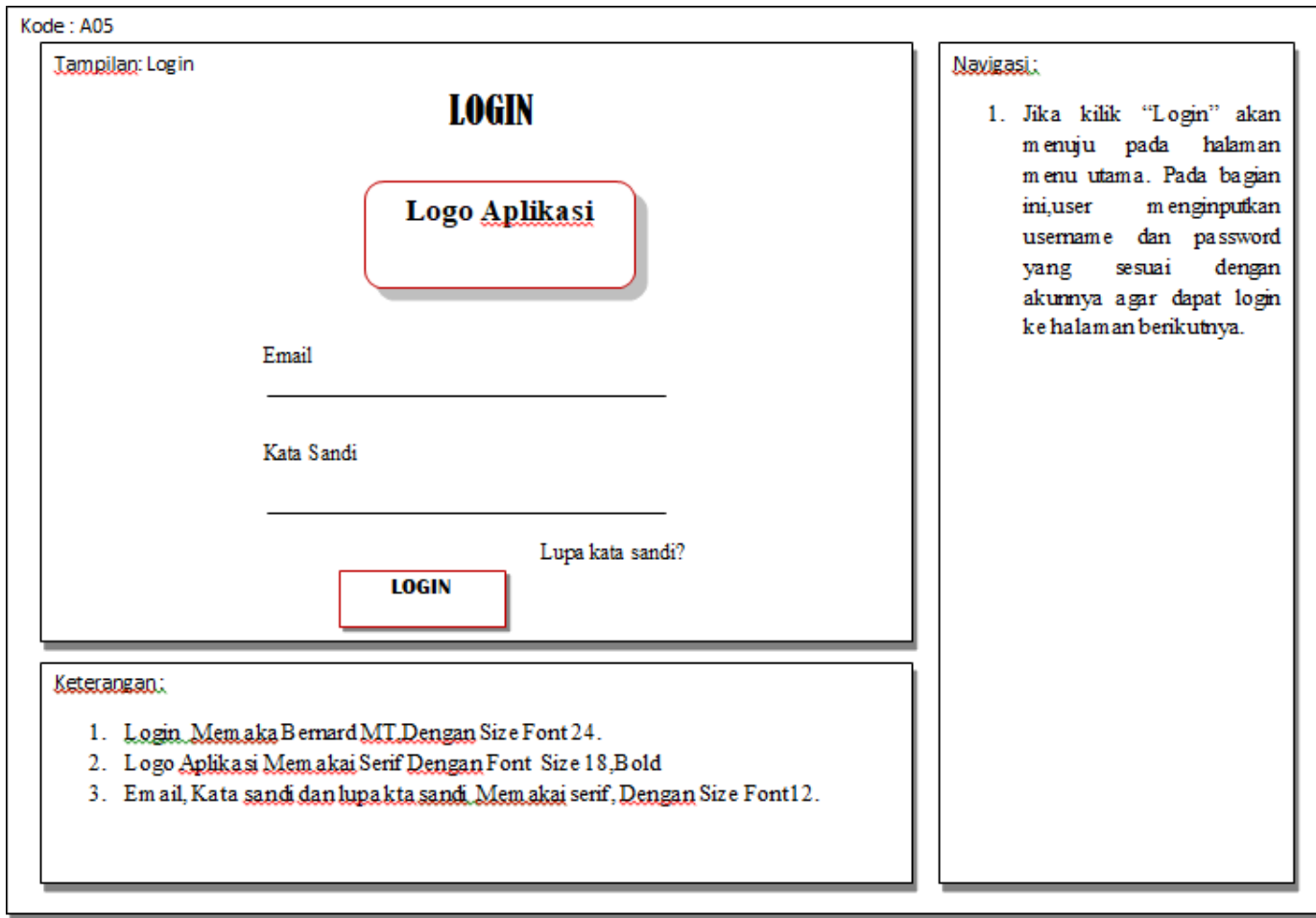

Gambar 3.5.1. 5 LKT Login 


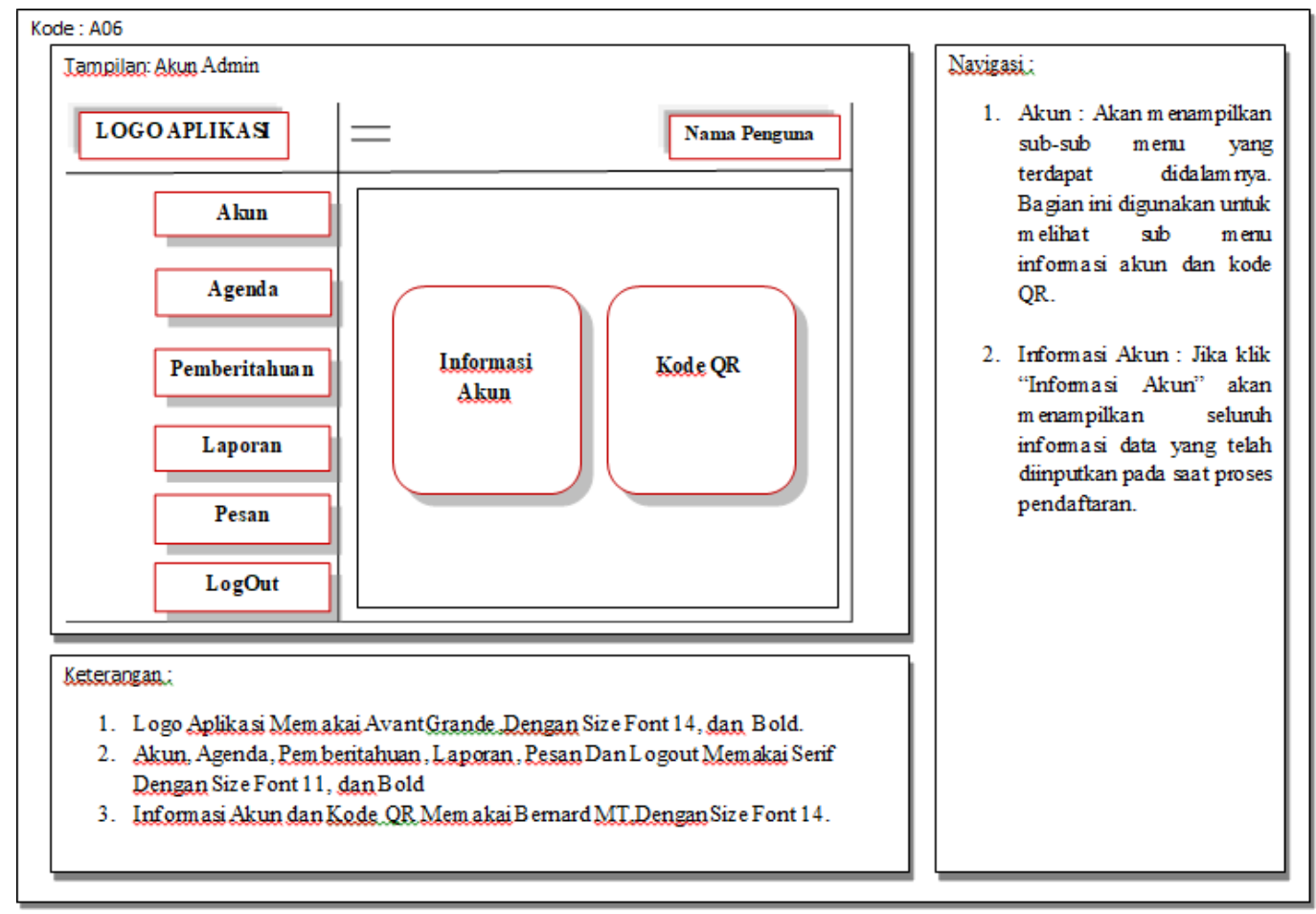

Gambar 3.5.1. 6 LKT Akun Admin

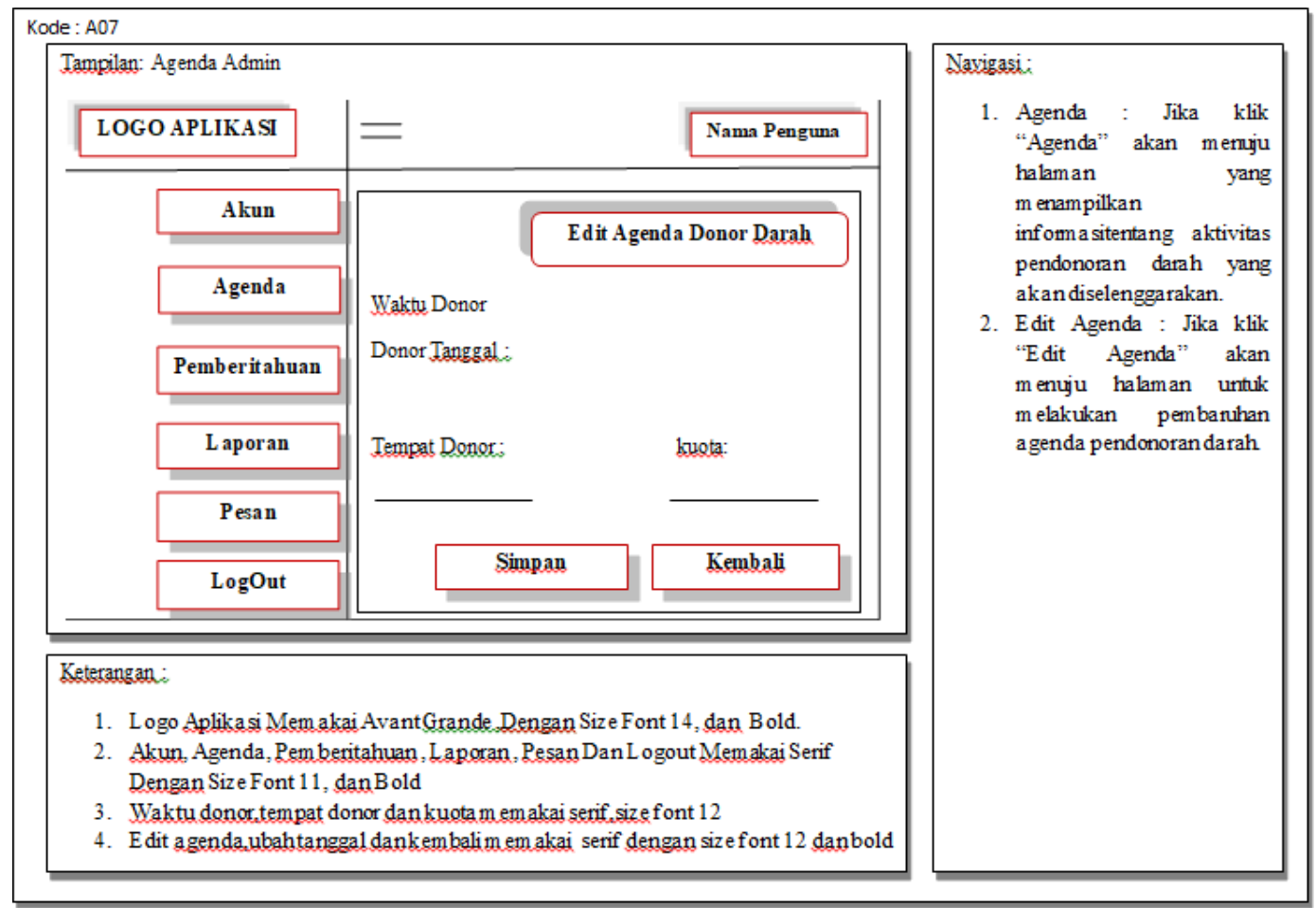

Gambar 3.5.1. 7 LKT Agenda Admin 


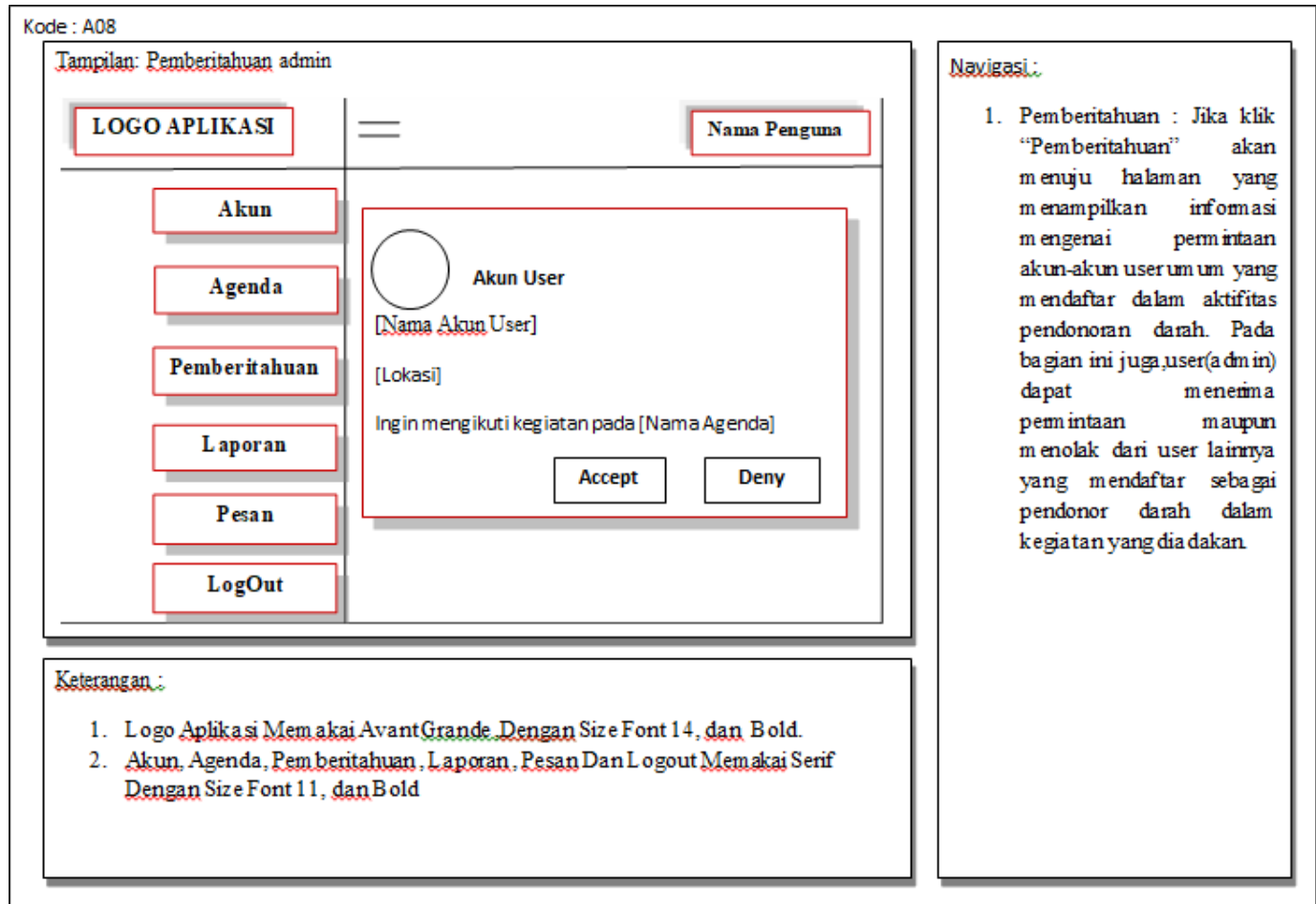

Gambar 3.5.1. 8 LKT Pemberitahuan Admin

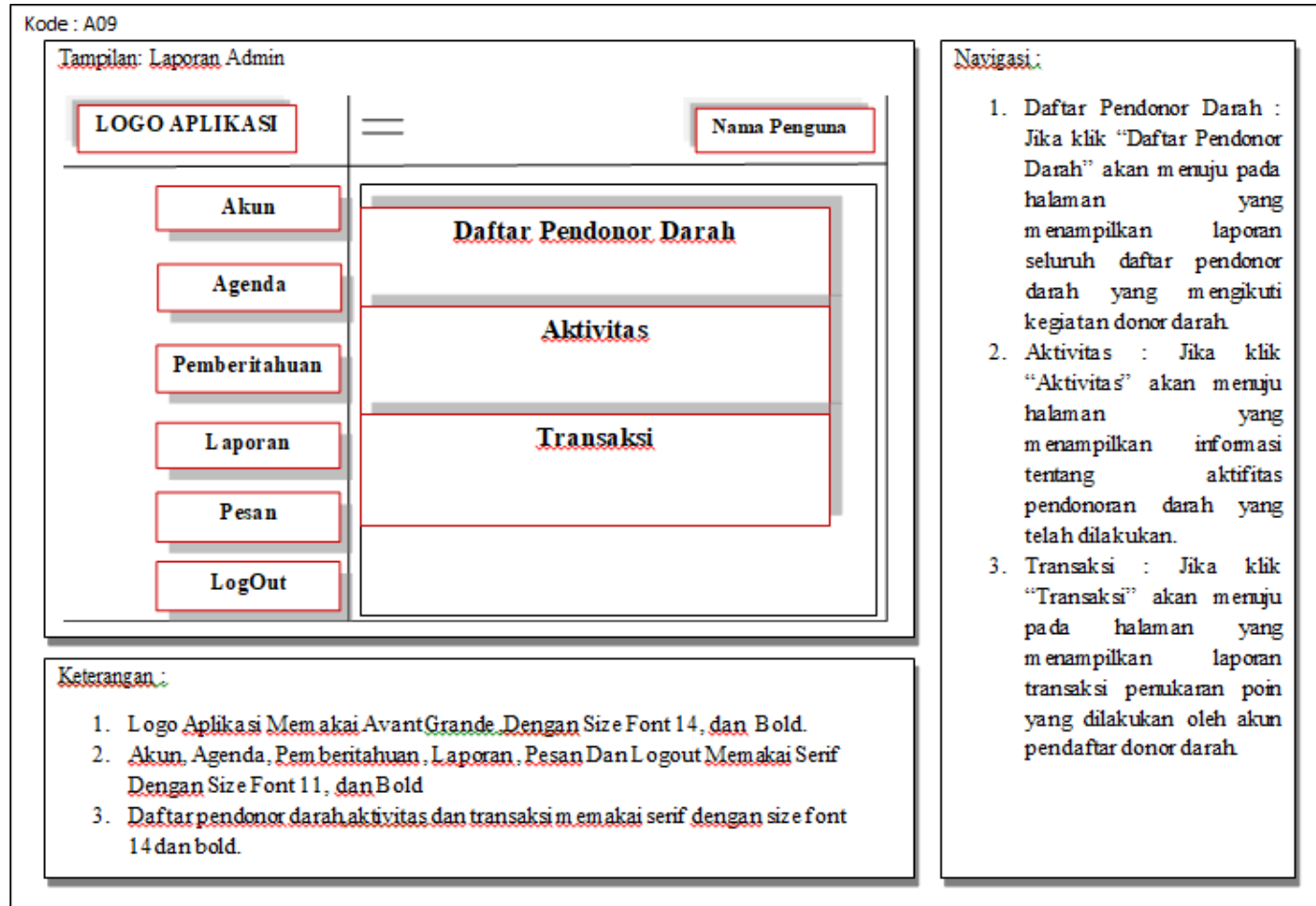

Gambar 3.5.1. 9 LKT Laporan Admin 


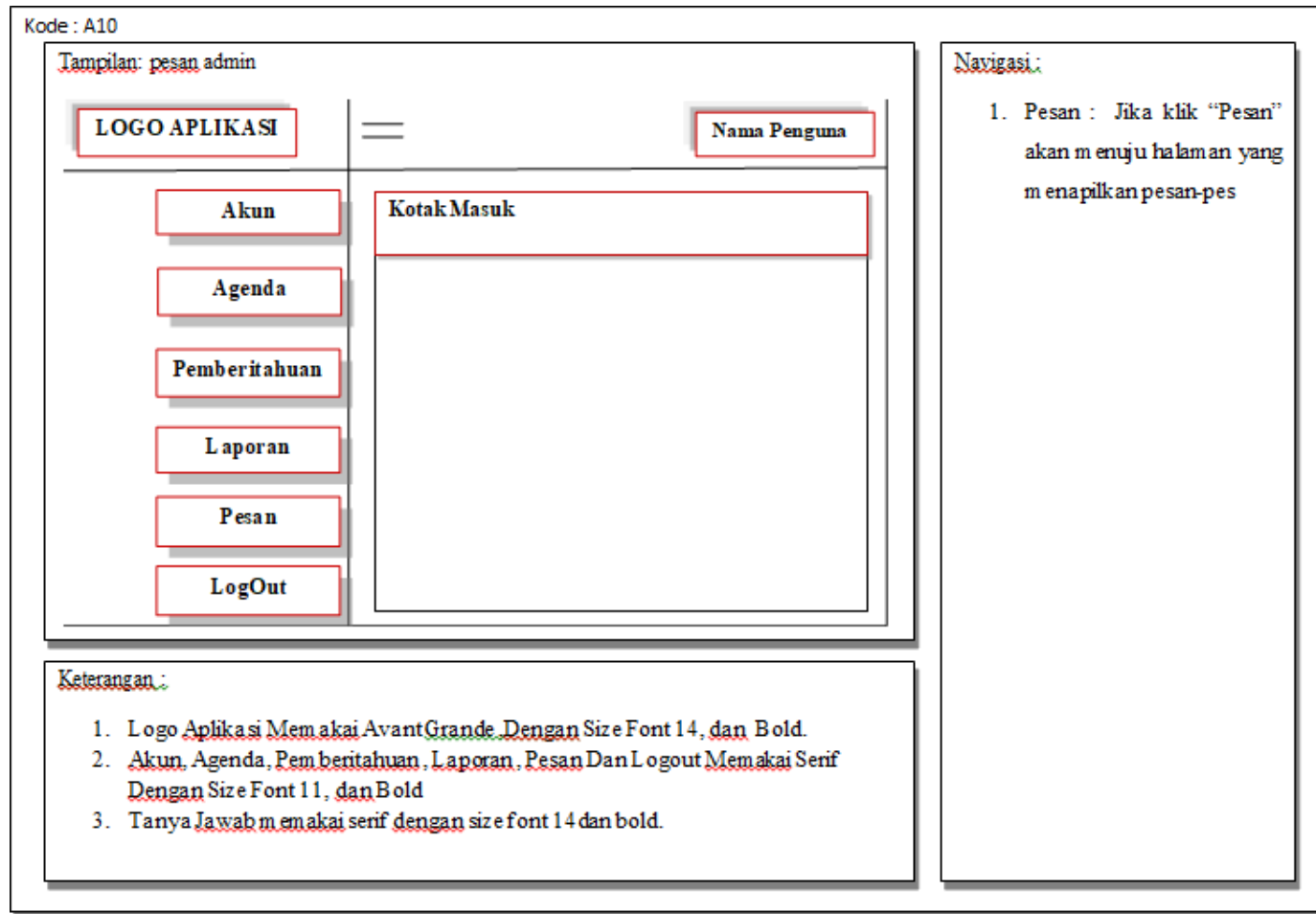

Gambar 3.5.1. 10 LKT Pesan Admin

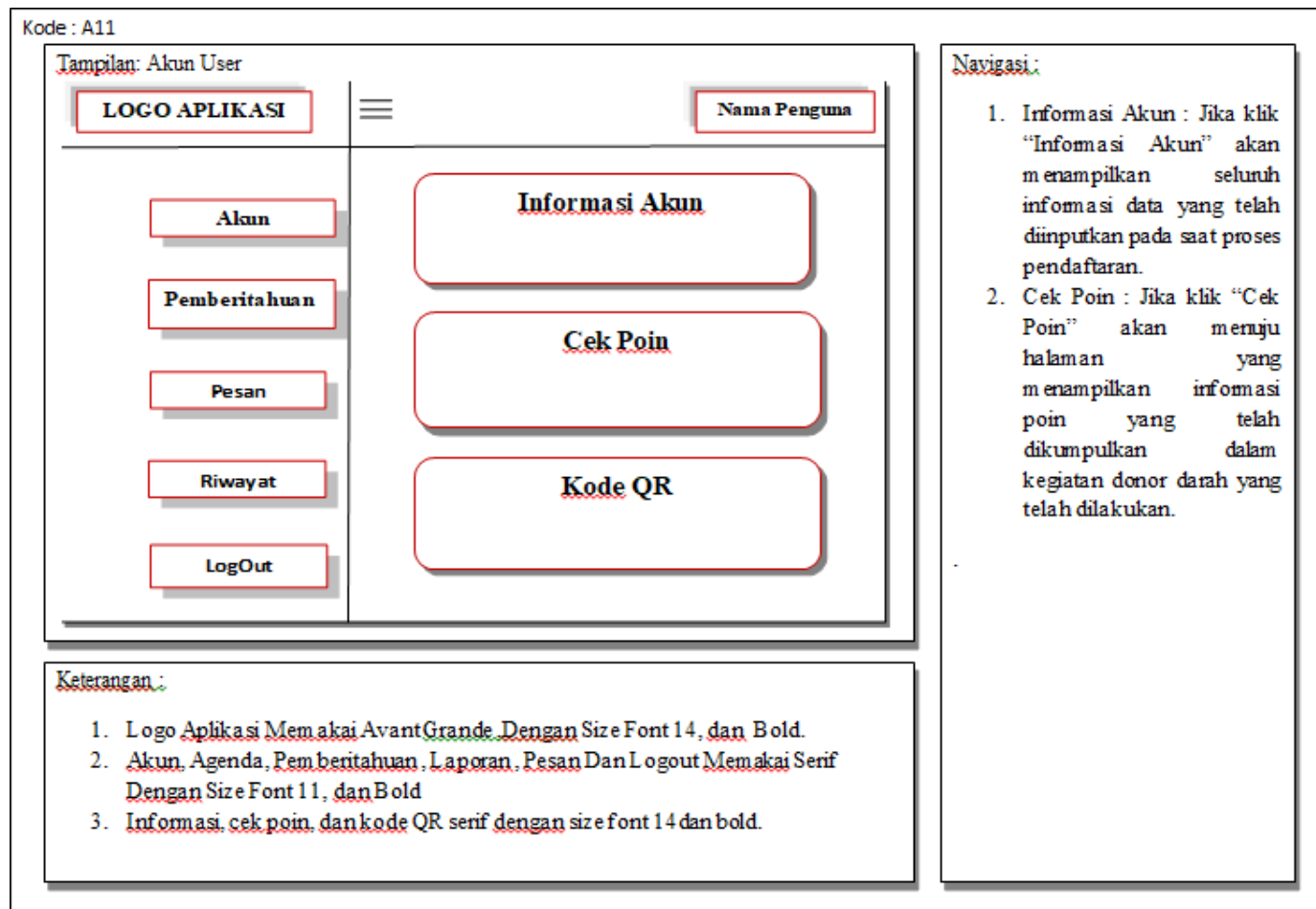

Gambar 3.5.1. 11 LKT Akun User 


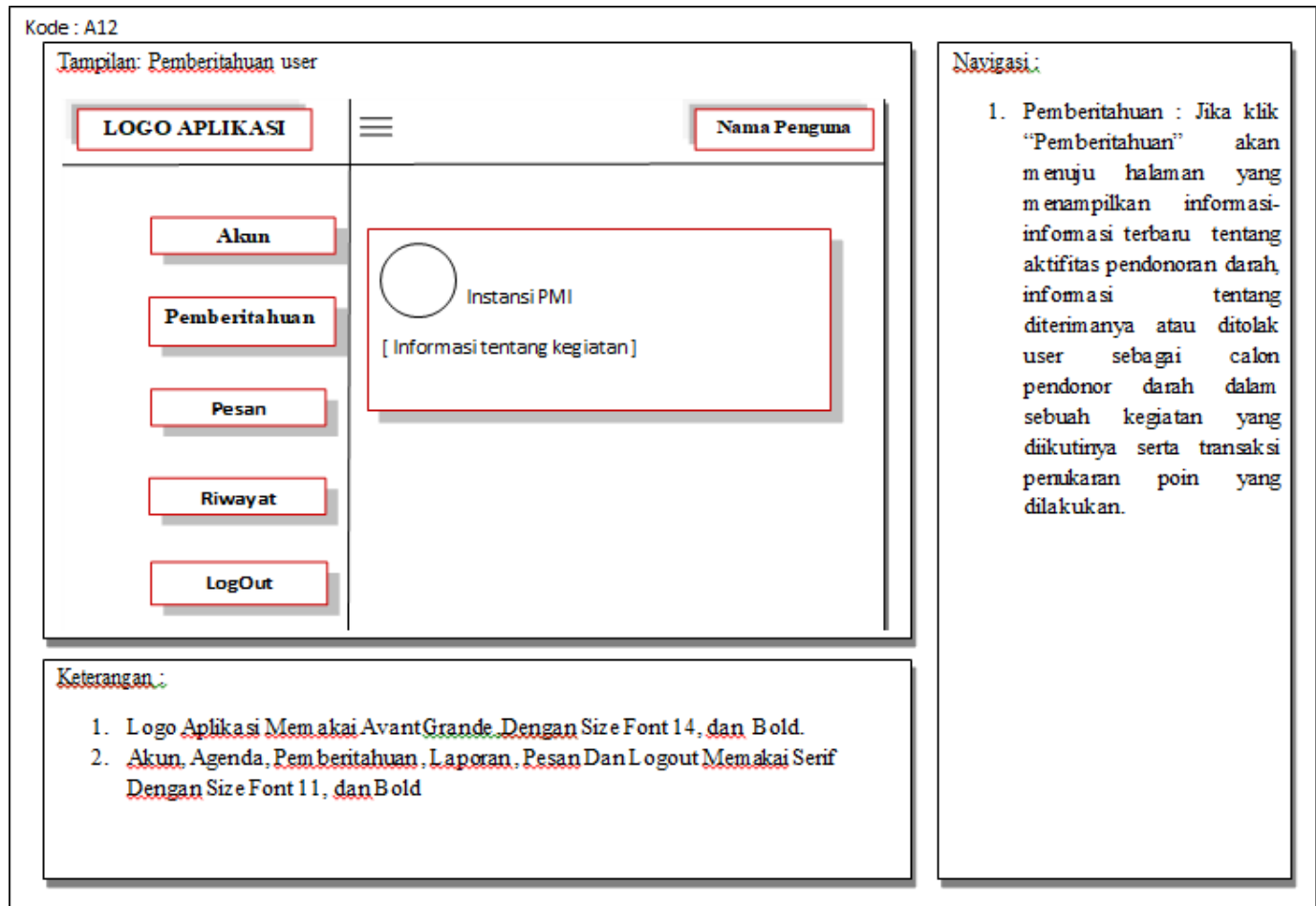

Gambar 3.5.1. 12 LKT Pemberitahuan User

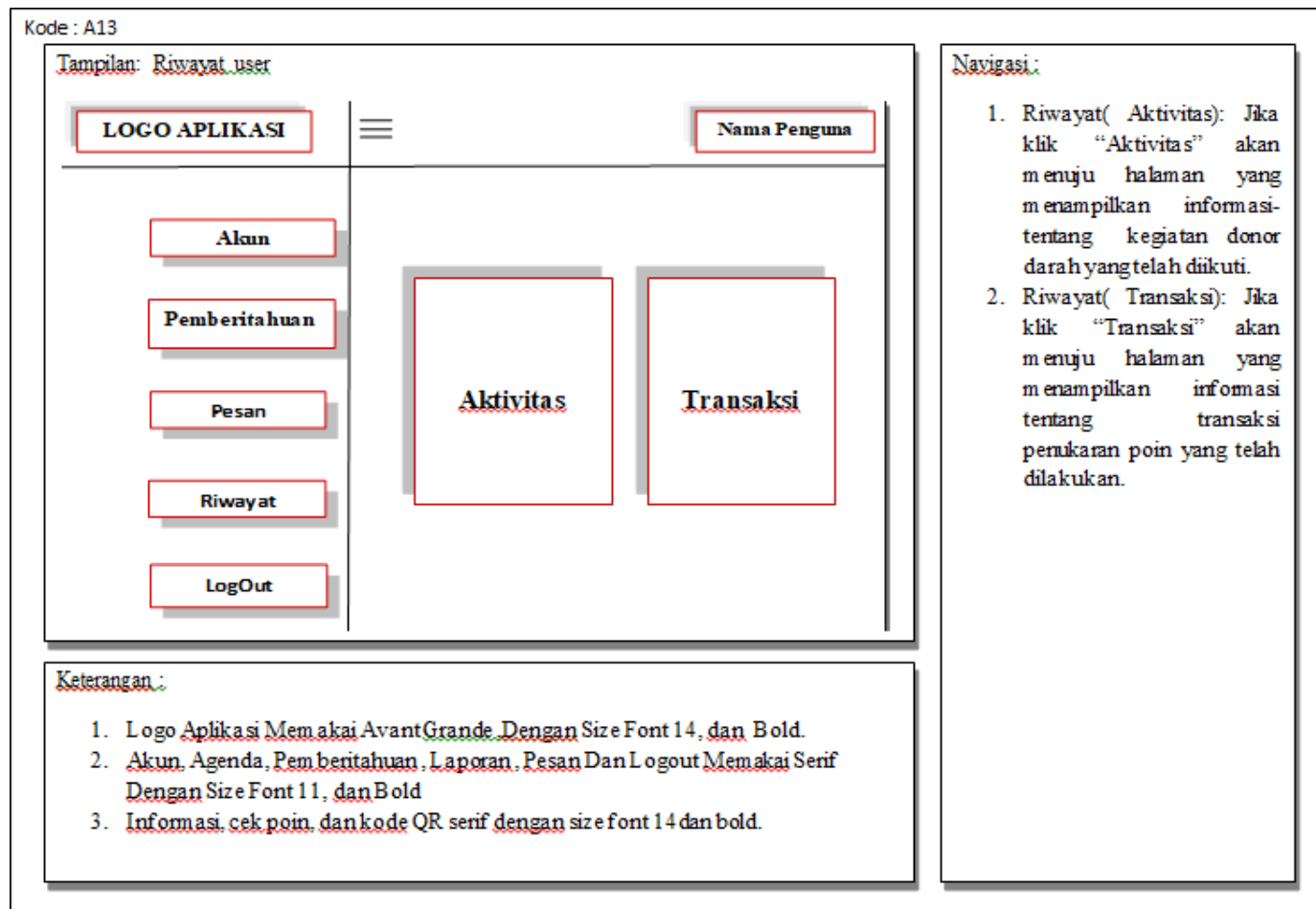

Gambar 3.5.1. 13 LKT Riwayat User 


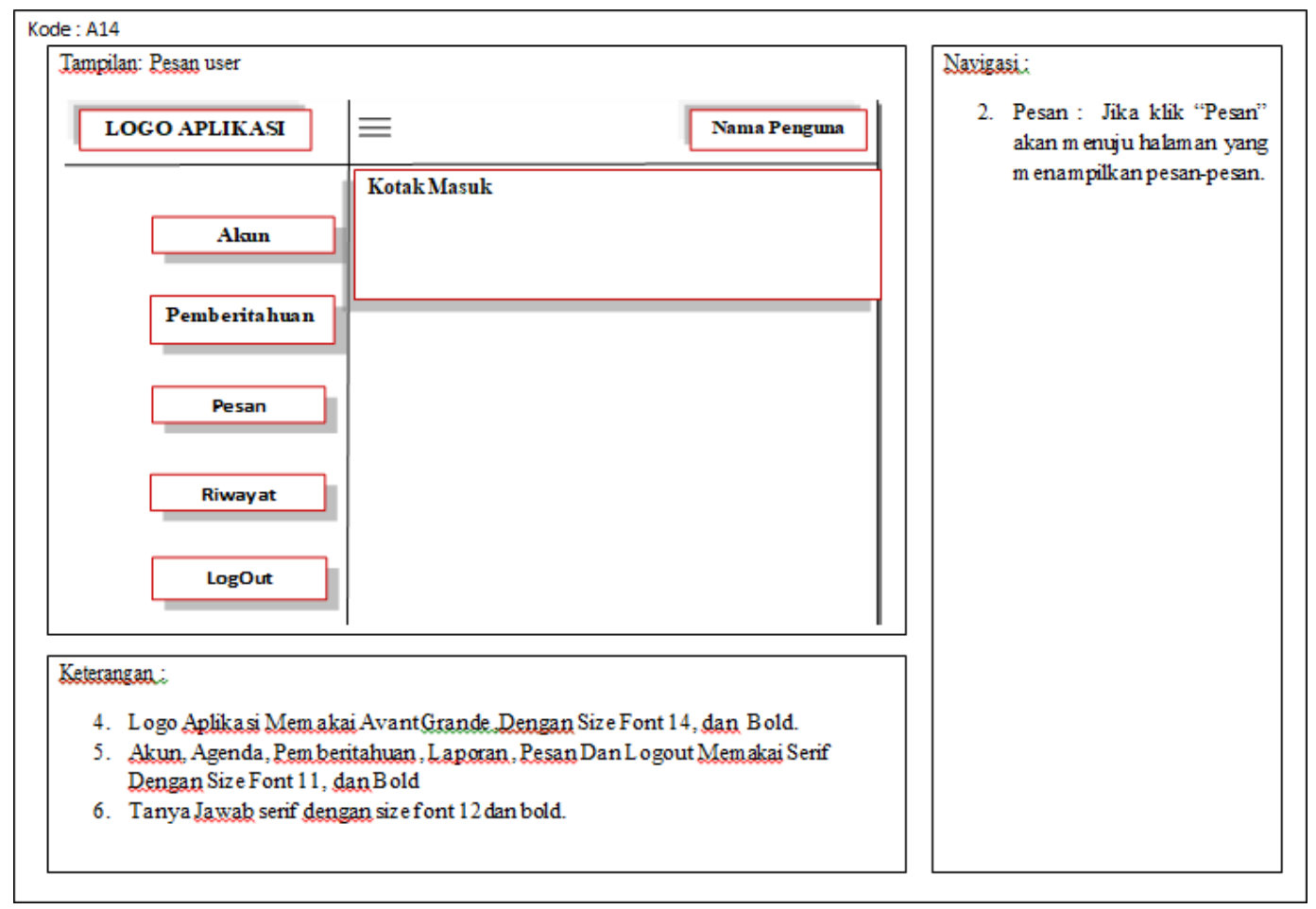

Gambar 3.5.1. 14 LKT Pesan User

\section{b.Jaringan Semantik}

Jaringan Semantik, merupakan teknik representasi kecerdasan buatan klasik yang dibunakan untuk informasi proporsional. Jaringan semantik kadang disebut juga dengan "proportional net".Jaringan semantik merupakan jaringan data dan informasi, yang menentukan hubungan berbagai objek dimana informasi yang terhubung tersebut adalah informasi yang proporsional. Representasi jaringan semantik merupakan penggambaran grafis dari pengetahuan yang memperlihatkan hubungan hirarkis dari objek-objek. Berikut jaringan semantik dari Aplikasi “ Donor Darah “ : 


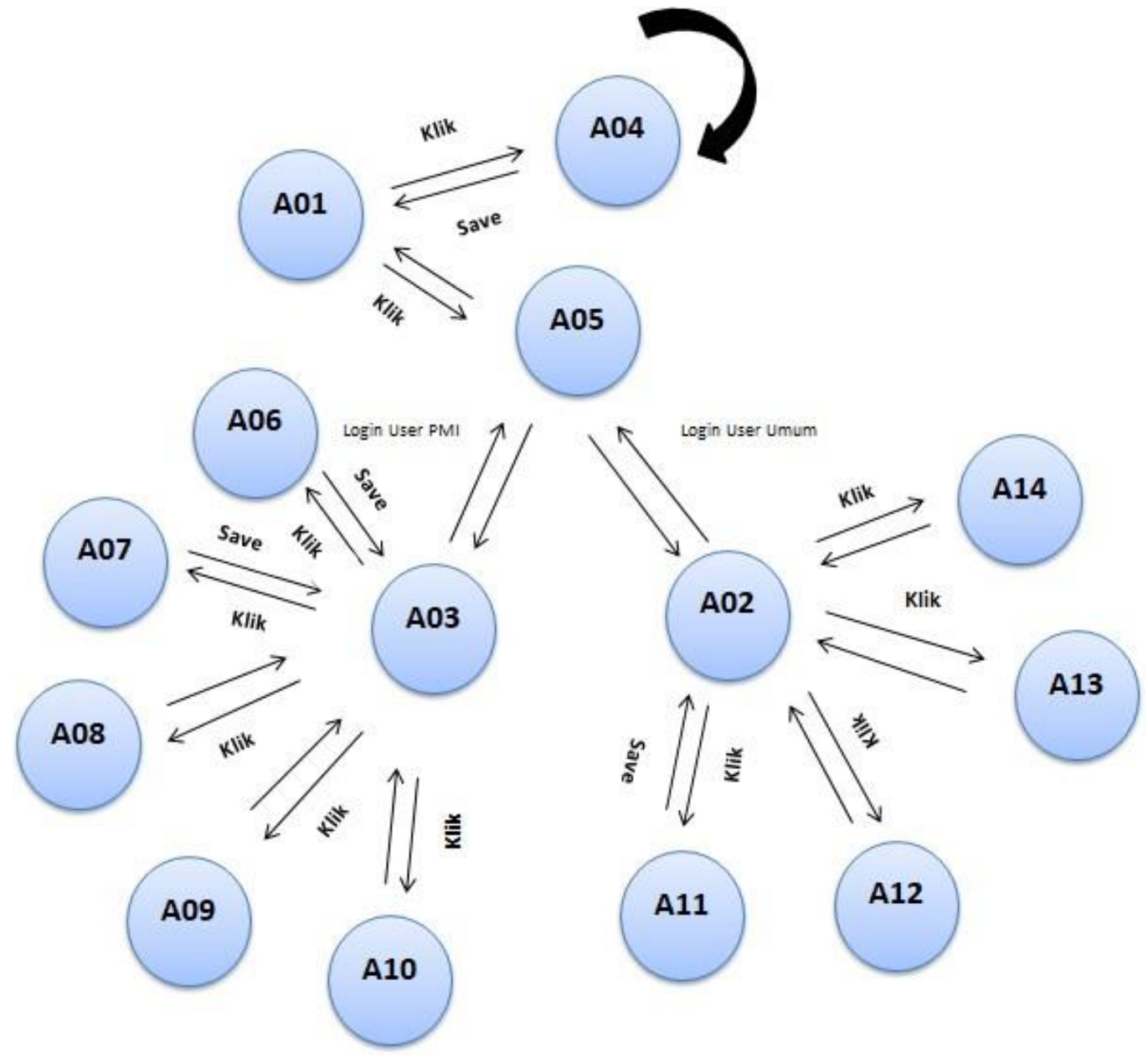

Gambar 3.5.2. 1 Jaringan Semantik Aplikasi Donor Darah

\section{KESIMPULAN}

Dalam pembuatan rancangan aplikasi Donor Darah ini, langkah awal yang harus ditentukan adalah metode pengembangan perangkat lunak yang akan digunakan. Pemilihan penggunaan metode ini berkaitan dengan tujuan perancangan aplikasi dan manfaat yang didapat dalam proses pengembangan perangkat lunak. Metode Waterfall merupakan metode yang kami pilih untuk merancang aplikasi Donor Darah ini, karena tujuan aplikasi yang kami rancang sudah cukup jelas dan memberikan manfaat bagi kami karena aturan pengerjaan metode Waterfall ini adalah bertahap dan berurutan, sehingga dalam pengerjaannya dapat dimaksimalkan tahap demi tahap. Langkah-langkah dalam metode Waterfall harus dikerjakan secara benar agar dapat mengerjakan langkah selanjutnya. Dalam perancangan aplikasi donor darah ini, kami megerjakan 2 dari 5 tahapan yang ada di dalam metode waterfall. Tahap pertama yaitu analisis kebutuhan, pada tahap ini kelompok kami berdiskusi untuk mengetahui kebutuhan pengguna dan batasan-batasan dalam pembuatan software. Tahap kedua yaitu desain sistem, pada langkah ini kami membuat ERD berupa use case, membuat skenario, 
navigasi, prototype, lkt dan jaringan semantic.

Diagram use case digunakan untuk memahami fungsi apa saja yang ada di dalam sebuah sistem dan siapa saja yang dapat menggunakan fungsi-fungsi tersebut. Dalam tahap desain sistem, navigasi digunakan sebagai alur untuk mengarahkan user pada tugasnya. Navigasi yang digunakan dalam desain sistem aplikasi " Donor Darah" adalah navigasi hirarki. Karena navigasi sistem merupakan navigasi bercabang dan terstruktur yang dikelompokkan berdasarkan karakteristik nya. Berikutnya adalah scenario, Skenario dapat dikatakan sama dengan sebuah alur atau langkah pengerjaan agar pekerjaan dapat terbantu dan fokus pada apa yang ingin diciptakan atau dibuat, dimana skenario menceritakan alur dari awal aplikasi "Donor Darah" sampai akhir. Selantutnya menentukan prinsip yang akan digunakan pada aplikasi Donor Darah dangan berpatokan pada 16 prinsip desain antarmuka.

Salah satu kriteria penting dari sebuah antarmuka adalah tampilan yang menarik. Yang harus dimiliki oleh perancang tampilan adalah iwa seni yang memadai dan mengetahui selera user secara umum, bisa meyakinkan pemrogramannya, agar yang dibayangkan dapat diwujudkan dengan piranti bantu (tool) yang tersedia, serta endokumentasikan semua pekerjaan yang dilakukan. Seorang perancang tampilan harus mendokumentasikan semua pekerjaan yang telah dia kerjakan selama ini, sebagai bahan evaluasi pembuatan tampilan yang baru atau memperbaiki tampilan sebelumnya. Perancang seharusnya membuat dokumentasi akan bentuk-bentuk yang akan diimplentasikan menggunakan sketsa kertas kosong Peranti bantu Untuk mempermudah penamaan akan tetapi saya membuat lkt dalam bentuk office word. LKT pada dasarnya terdiri atas beberapa bagian, yaitu Nomor Lembar Kerja Bagian Tampilan berisi sketsa tampilan yang akan muncul dilayar, Bagian Navigasi: bagian ini antara lain menjelaskan kapan tampilan itu akan muncul, dan kapan tampilan itu berupah menjadi tampilan lain. Bagian Keterangan: bagian ini berisi penjelasan singkat tentang atribut tampilan yang akan dipakai.yang terakhir adalah Jaringan semantik, merupakan gambaran pengetahuan grafis yang menunjukkan hubungan antar berbagai obiek. Menunjukkan sejumlah lingkaran yang menggambarkan objek dan informasi deskriptif tentang objek-objek. Tahap-tahap selanjutnya yaitu coding dan testing, penerapan dan pengujian, serta pemeliharaan.

\section{DAFTAR PUSTAKA}

1) Kosasi, S. (2015). PERANCANGAN PROTOTIPE SISTEM PEMESANAN MAKANAN DAN MINUMAN MENGGUNAKAN MOBILE DEVICE. Teknologi Informasi Vol. 1 No. 02 Maret 2015, 184-185.

2) Septiani, L. (n.d.). Interaksi Manusia dan Komputer (IMK) - APLIKASI LAUNDRY ONLINE. Part Skenario Admin. Retrieved Oktober 6, 2020, from academia.edu: 
3) https://www.academia.edu/22749306/Interaksi_Manusia_dan_Komputer_I MK_APLIKASI_LAUNDRY_ONLINE_Part_Skenario_Admin

4) Sutanto, E. (2017). "PERANCANGAN APLIKASI DONOR DARAH UNTUK KOTA BANDUNG MENGGUNAKAN METODE PARTICIPATORY

5) DESIGN". Skripsi. Fakiltas Teknologi Industri, Teknik Industri, Universitas Parahyangan, Bandung. 19.

6) Tristianto, C. (2018). PENGGUNAAN METODE WATERFALL UNTUK PENGEMBANGAN SISTEM MONITORING DAN EVALUASI PEMBANGUNAN PEDESAAN. Jurnal Teknologi Informasi ESIT Vol. XII No. 01 April 2018 , 14-15.

7) http://e-journal.polnes.ac.id/index.php/justi/article/vi 
